Portland State University

PDXScholar

1983

\title{
Nineteenth century French and German interpretations of the early medieval Germanic invasions
}

James N. Owens

Portland State University

Follow this and additional works at: https://pdxscholar.library.pdx.edu/open_access_etds

Part of the Ancient History, Greek and Roman through Late Antiquity Commons, Comparative Literature Commons, and the European History Commons Let us know how access to this document benefits you.

\section{Recommended Citation}

Owens, James N., "Nineteenth century French and German interpretations of the early medieval Germanic invasions" (1983). Dissertations and Theses. Paper 3353.

https://doi.org/10.15760/etd.5236

This Thesis is brought to you for free and open access. It has been accepted for inclusion in Dissertations and Theses by an authorized administrator of PDXScholar. Please contact us if we can make this document more accessible: pdxscholar@pdx.edu. 
AN ABSTRACT OF THE THESIS OF James $N$. Owens for the Master of Arts in History presented February 15, 1983.

Title: Nineteenth Century French and German Interpretations of the Early Medieval Germanic Invasions. APPROVED BY MEMBERS OF THE THESIS COMMITTEE:

Michael F. Reardon, Chairman

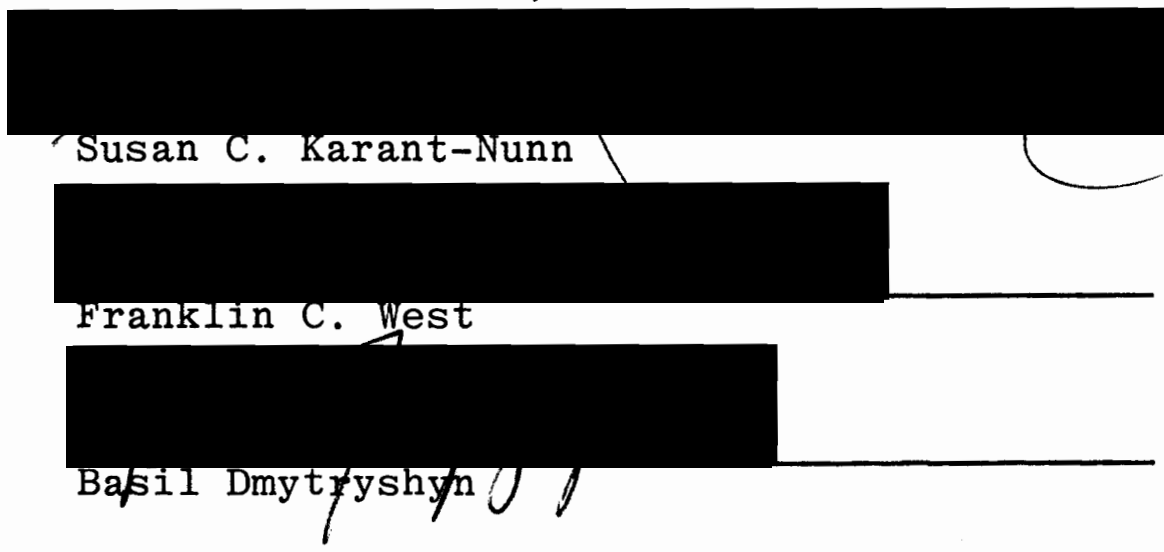

Various interpretations of the Germanic invasions of the early Middle Ages have been advanced. These present to the student of historiography a fertile field for inquiry. In this thesis the interpretations of the Germanic invasions propounded by Jules Michelet (1798-1874) and Gustav Freytag (1816-1875) are examined with a view to establishing the cultural context in which their mutually exclusive versions were formulated, and the extent to which that context lent the interpretations of both writers a perceptible national and aesthetic bias. 
NINETEENTH CENTURY FRENCH AND GERMAN INTERPRETATIONS OF THE EARLY MEDIEVAL GERMANIC INVASIONS

by

JAMES $N$. OWENS

A thesis submitted in partial fulfillment of the requirements for the degree of

MASTER OF ARTS

in

HISTORY

Portland State University

1983 
TO THE OFFICE OF GRADUATE STUDIES AND RESEARCH:

The members of the Committee approve the thesis of James N. Owens presented February 15, 1983.

Michael F. Reardon, Chalrman

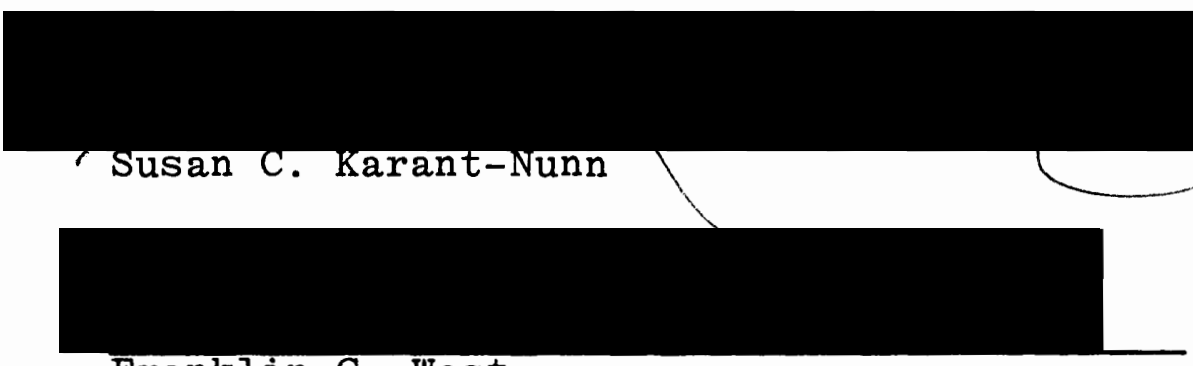

Franklin C. West

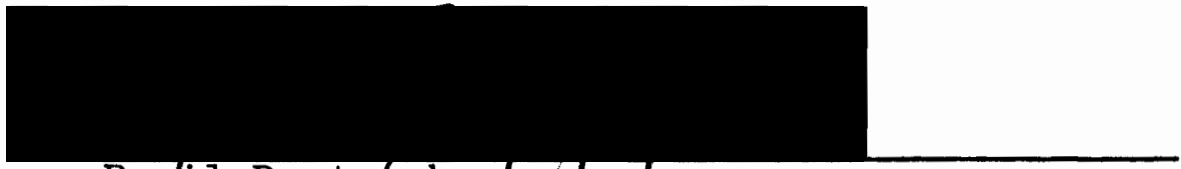

Basil Dmytrosshyn $0 /$

APPROVED :

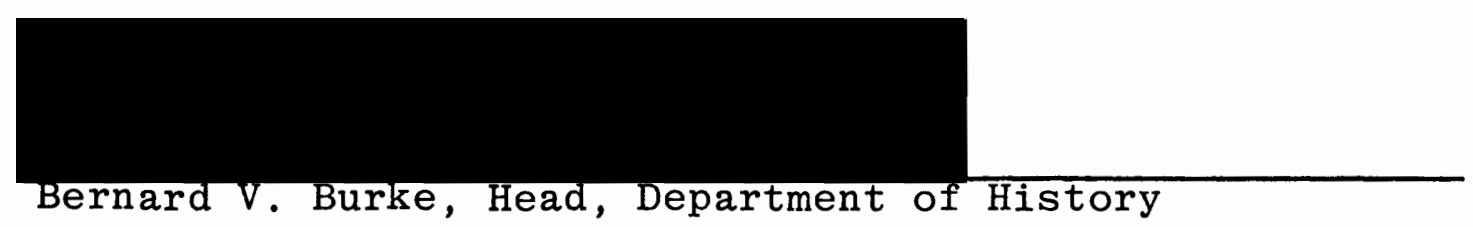

Stanley E. Rauch, Dean of Graduate Studies and Research 
TABLE OF CONTENTS

PAGE

INTRODUCTION $\ldots \ldots \ldots \ldots \ldots \ldots \ldots \ldots \ldots \ldots \ldots \ldots \ldots \ldots \ldots$

CHAPTER

I THE BACKGROUND OF HISTORICISM $\ldots \ldots \ldots \ldots \ldots 6$

I I NINETEENTH CENTURY NATIONALISM $\ldots \ldots \ldots \ldots \ldots 17$

French Nationalism ............. 18

German Nationalism ............. 21

The Symbiotic Relationship of French and German Nationalism .............. 30

I I ROMANTICISM IN FRANCE AND GERMANY $\ldots \ldots \ldots .37$

German Romanticism ............. 39

Friedrich von Hardenburg (Novalis)

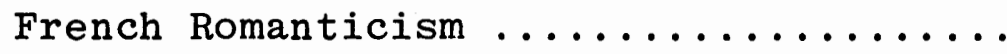

Francois Chateaubriand

Conclusion $\ldots \ldots \ldots \ldots \ldots \ldots \ldots \ldots$

IV JULES MICHELET AND THE "BARBARIAN

INVASIONS" $\ldots \ldots \ldots \ldots \ldots \ldots \ldots \ldots \ldots \ldots \ldots \ldots \ldots \ldots \ldots$

$\mathrm{V}$ GUSTAV FREYTAG AND THE VÖLKERWANDERUNG $\ldots . .97$

VI HISTORICISM, NATIONALISM, AND ROMANTICISM

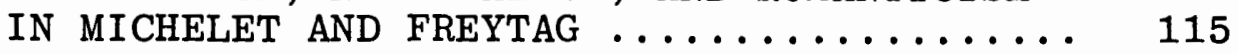

A SELECTED BIBLIOGRAPHY $\ldots \ldots \ldots \ldots \ldots \ldots \ldots \ldots \ldots \ldots \ldots$ 


\section{INTRODUCTION}

The nineteenth century witnessed the development of a widespread curiosity concerning the past. This phenomenon can be attributed to no single cause; it was rather the result of a complex of factors. Among these factors must surely be included the emergence of the attitudes associated with modern nationalism and the movement in the arts referred to as romanticism.

The nineteenth century has been identified as an era of strident nationalism by many scholars, none of whom has been more forcefully eloquent than Hans Kohn. ${ }^{1}$ The French Revolution, whatever other consequences it may have had, transformed France from a feudal kingdom into a nationstate whose citizens desired, or were persuaded to accept, a certain image of themselves as Frenchmen and of France as a nation. In Germany, it was opposition to the French domination which impelled Germans to discover or fabricate an identity for themselves as Germans and for politically fragmented Germany as a nation spiritually, if not territorially, united. Frequent return will be made to these points, in an attempt to determine in what manner and to what extent they apply to the work of Jules Michelet and Gustav Freytag. 
All of the arts during the first half of the nineteenth century were characterized to a greater or lesser degree by a desire on the part of the artist to depict the exotic. "Exotic" often translated as "remote," with the element of remoteness being supplied either by distance in time or distance in space. It is the distance in time that is of concern here. One of the distinguishing characteristics of romantic literature was its predilection for the Middle Ages as a setting for fiction tending to idealize that period of European history. ${ }^{2}$ Walter Scott's Ivanhoe and Chateaubriand's Les Martyrs may be regarded as examples of a tendency general among the romantics to view the Middle Ages as one form or another of the "good old days." Goethe had created the type of the romantic hero in The Sorrows of Young Werther; romantic writers were to produce variations of this hero and his corresponding heroine throughout the nineteenth century.

Two general characteristics of the nineteenth century have been identified: a desire of the European peoples to be informed about the earlier history of their homelands; and the dominance, especially during the first half of the century, of the romantic movement in the arts.

It is the premise of this thesis that these two trends are closely interrelated, that each influenced and reacted on the other. This premise may be established by an examination of nineteenth century historical writing, 
and in particular through an analysis of the interpretations of the early medieval Germanic invasions offered by a representative French and German historian.

The choice of Jules Michelet (1798-1874) and Gustav Freytag (1816-1875) for purposes of comparison has been largely determined by their popularity. They figured as influential shapers of public opinion, and indeed both men viewed themselves as writing primarily for the "common man." In studying Michelet and Freytag one is dealing with historical interpretations which found acceptance with a wide public, and which can therefore provide insight into popular conceptions of the national past of France and Germany prevalent in the last decades of the nineteenth century.

The choice of Michelet and Freytag was also influenced by the nature of their interpretive differences regarding the medieval Germanic invasions. These differences arose not solely from obvious identification with their respective nation-states, but also from implicit assumptions they made concerning the ultimate historical questions and the role of the historian as an investigator of those questions. It will be seen that Michelet and Freytag gave nearly identical answers to the questions "What is history?" and "What is the historian's task?" My own assumptions and biases ought to be clearly stated at this point. They are generally "historicist" as 
that term will be defined in the following pages. In preparation for this discussion the relevant texts of Michelet, Freytag and their contemporaries were treated as primary sources of a definite type of historical interpretation which first became popular in the last century. But I was convinced that Michelet and Freytag could not be fully understood until placing them within the larger contexts of historicism, nationalism and romanticism. 3 Though their names appear in the title, it is not Michelet and Freytag who are the main subjects of this study, but certain ideas about history and the uses to which they have been put.

Before any attempt can be made to evaluate the work of Jules Michelet and Gustav Freytag it is important to establish the cultural context in which they worked. If distortion is to be avoided, we must possess some clear idea of the content of nationalism in nineteenth century France and Germany. It is equally important to understand certain traditions within European historiography. 
NOTES : INTRODUCTION

${ }^{1}$ Prelude to Nation-States (Princeton: Van Nostrand,
1971). This volume is in fact a synopsis of several
earlier volumes by Kohn. See Bibliography. Kohn's
reputation is due at least as much to his criticism of
nationalism as to his extensive studies of it. But it
should be borne in mind that Kohn is sometimes guilty of
making his point by overstatement.
$\quad{ }^{2}$ G. Brandes, Main Currents in Nineteenth Century Literature, 9 vols. (New York: Boni \& Liverwright, 1923). Although published over a century ago, Brandes' work is valuable for its insight, but also displays the later nineteenth century tendency to disparage romanticism, on utilitarian and rationalistic grounds, as escapist and irrational. Vols. II and V treat the German and the French romantics respectively.

${ }^{3}$ Hayden V. White further elaborates this approach to historical sources and historical writing, labeling it "Contextualist" to distinguish it from "Formist," "Mechanist" and "Organicist" orientations in Metahistory: The Historical Imagination in the Nineteenth Century (Baltimore: Johns Hopkins Press, 1973), pp. 17-19. 


\section{CHAPTER I}

\section{THE BACKGROUND OF HISTORICISM}

"Historicism" is most often associated with relatively recent developments in historiography, and is too often linked with a German tradition of the late nineteenth and early twentieth centuries. This narrow definition of historicism may, as recent scholarship has shown, result in an overly simplified and superficial view. While it is true that "historicism" was coined in the late nineteenth century to denote a specific approach to history best exemplified by several German historians, a restriction of the meaning of historicism to Friedrich Meinecke's definition subtly discourages inquiry into the position of historicism in the wider European historiographical tradition. ${ }^{1}$

Meinecke (1862-1954) was one of historicism's most eminent spokesmen. It is therefore no surprise that historicism would assume for him the character of an unprecedented breakthrough in historical interpretation. Weltburgertum und Nationalstaat downplays historicism's debt to previous historiographical tradition, and emphasizes those elements of historicism regarded by Meinecke as completely novel and unique. ${ }^{2}$ 
Historicism need not, however, be defined in terms put forth by its apologists. Historicism as a concept is sufficiently broad to permit definition in terms considerably more flexible than those which would confine historicism to a specific period of time or to historians of a specific nation. Donald R. Kelley has undertaken an articulation of this broader definition. Kelley argues that Renaissance philology, due to the nature of philology itself, could not but give rise to habits of mind which are essentially those necessary for the historicist attitude, even in its strictest definition. Kelley observes that the discipline of textual criticism

established a point of view dependent on the study of things in terms of time, place, and circumstance. It provided a 'historical' method and certain concepts, such as those of style and anachronism, essential for the interpretation of cultural history. 3

This observation is nothing new, however. It was also made by Lorenzo Valla (1407-1457), who discovered that the supposed Donation of Constantine could not possibly have dated from the fourth century because the style of Latin in which it was composed belonged to a much later time. Valla's awareness that Latin had undergone modifications in style and content through time was shared by contemporary humanists. Renaissance humanists sought to "purify" Latin texts in order to approach more closely the culture of classical antiquity, which they revered as a 
golden age. ${ }^{4}$ They viewed language as an eloquent vehicle of culture. Yet the fact that such "purification" was necessary forced humanist scholars to recognize, often against their inclinations, that the past might have been very different from the present. If language had changed with time, might not the cultural values expressed by language also have changed? Philology is the study of language in amounts of time, and from pure philology it is a short step to the study of culture in terms of time. Without the awareness of change in language there could be no philology. A sensitivity to change on the part of Renaissance humanists led to an attitude toward the past which was then entirely novel, but which has definite affinities with the way we view the past today: the past is always different from the present, and no two past periods are identical. 5 According to Kelley, the Renaissance humanists were "historicist" in their attitude toward the past because historicism does not have to mean only what Meinecke or Troeltsch wanted it to mean. Kelley opts for more continuity in European historiography than Meinecke seemed willing to accept. For Kelley, historicism is no more and no less than a general attitude

which emphasizes the variety rather than the uniformity of human nature; which is interested less in similarities than in differences; and which is impressed not with permanence, but with change. 6 
In insisting on the historicism of Renaissance humanists, Kelley is perhaps doing violence to the etymology of the term; but he is also implying that the work of Meinecke and others, which is historicism properly so called, was in fact a late phase of a tradition of historical thought having its beginnings in the Renaissance. The late, German variety of historicism eventually undermined its own validity with the relativism which it demanded of historical interpretation. 7 Though relativism is inherent in any attitude "impressed not with permanence but with change," the fifteenth and sixteenth century humanists avoided the consequences of relativism pushed to its logical conclusion. They were, with few exceptions, convinced that history follows a plan ordained by the Christian God.

G. Huppert, in his The Idea of Perfect History, corroborates Kelley's findings as to the antecedents of historicism. Though Huppert objects to the term "historicism" and prefers the more neutral "historical mindedness," his position is even more definite than Kelley's. "Neither Locke's psychology nor the scientific revolution seem to have prerequisites for the growth of a sense of history as we understand it." 8 Huppert maintains that this state of mind was not uncommon among French scholars before 1600 . In his final chapter, Huppert concludes that

the modern historical mentality--with all that this implies--can no longer be regarded as a by-product of the scientific revolution. The modern method 
of explaining the past was created in the sixteenth century. It ${ }_{9}$ fed on the achievements of humanist erudition.

Kelley and Huppert, then, push the appearance of modern historical consciousness back well beyond its customary location in the eighteenth century. In so doing, they have provided an expanded definition of historicism which gives the term a significance not dependent on its nineteenth and twentieth century connotations. 10

Kelley's and Huppert's concept of historicism as constituting a long historiographical tradition will be used in the following pages. The writer is in agreement with Kelley and Huppert that the transition from the medieval to a modern approach to the past occurred not in the eighteenth but in the sixteenth century, and was one of the by-products of humanist philology.

A sense of anachronism, or the lack of it, is the keystone of the Kelley and Huppert view: modern historical consciousness is pervaded with the sense of anachronism, but in medieval consciousness this sense is absent. Medieval chroniclers, as a rule, persisted in attributing to the princes and peoples of the most remote times the mores and motives current in their own day. ${ }^{11}$ Previous generations and their affairs were perceived as valuable subjects of study not for themselves, but as apt models for present behavior. G. H. Nadel has designated this type of historical writing as "exemplar history."12 Exemplar 
history treats the past as a source of good and bad examples of how rulers and subjects conduct themselves. That medieval politics and societies might be rather different from the politics and societies of antiquity did not occur to many medieval minds. This meant that the historian's task was not one of analysis and description of the "otherness" of the past. In simplest terms, the conscientious historian selected, from a past at least resembling (if not identical to) the present, certain models of the figure of the "good prince" and offered them as examples for the behavior of his own particular prince.

But their philological studies forced the Renaissance humanists to recognize the "otherness" of the past. The humanists developed a sense of anachronism. Of course, exemplar history continued to be written after the Renaissance, and is being written today. But after the Renaissance exemplar history could only represent a return to an earlier tradition. The historicist approach to the past first adumbrated by humanism was to be the direction in which European historiography was to develop in the following centuries.

It might be objected that an insistence on a broad definition of historicism is perhaps beside the point in a thesis whose subject is an examination of nineteenth century French and German interpretations of the early medieval Germanic invasions. But it is because this paper 
deals with nineteenth century historiography that it is especially important to demonstrate that historicism is, in essence, not specific to the nineteenth century. In terms of the broad definition, virtually all post-Renaissance historians have been historicists, regardless of their nationality. This is not to belittle the achievements of nineteenth century Historismus; it is to indicate that, in F. L. Borchardt's words,

Historiographers often forget that the great nineteenth century compilations of national antiquities and historical sources followed an unbroken chain from the sixteenth century predecessors.13

The compilations to which Borchardt refers were in France in Germany motivated by a consciousness of national identity which desired that the national past be preserved. ${ }^{14}$ A national consciousness does not appear suddenly, however. What we would today call a sense of national identity had been percolating, like historicism, since the Renaissance. Yet a sense of national identity is not quite identical of nationalism as understood in its nineteenth century manifestations. 15

Historicism, by virtue of its concentration on differences and change, was an approach to the past well suited to illustrate the differences between the various peoples of Western Europe; between "nations" in the original sense of the word. History was also conceived as the story of separately but similarly evolving "nations" by 
the eighteenth-century humanist Giambattista Vico, who used the philological analysis of classical literature to construct a philosophy based on the study of history. This philosophy gave precedence to history over the "exact" or "pure" sciences of mathematics and physics, and it will be seen that Michelet was to rely heavily on Vico's vindication of history in the construction of his own specifically French conception of the past.

History came to be, very understandably, employed as an aid in defining "Frenchness" and "Germanness." This use of history assumed what are, to date, its most extreme forms during the nineteenth century, yet these histories were the culmination of a tradition of historical thinking whose age of four hundred years had made respectable. 
NOTES: CHAPTER I

${ }^{1}$ It is misleading to suggest that Meinecke had any formal definitions; in fact, there was for him not one, but several definitions of historicism, and he sometimes was deliberately vague about it, intending to keep historicism as a concept flexible enough to be useful to any historian. Despite the title, his Die Entstehung des Historismus, recently translated by J. E. Anderson as Historicism (New York: Herder \& Herder, 1972) is a survey of historiography up to Ranke. It breaks off where historicism as practiced by Meinecke begins, but is valuable as a background. Weltburgertum und Nationalstaat (Vol. 5 of collected works, ed. and with an introduction by Hans Herefeld (Munich: Oldenbourg, 1962)) provides many examples of Meinecke's definitions of historicism, all of which share the common conviction that historicism is a totally new attitude toward the past, absolutely unique and specific to the late nineteenth century. While this makes sense within the context of Weltburgertum und Nationalstaat, it is too narrow to stand outside the work as a functional definition of historicism. Others who have not considered themselves historicist have no difficulties defining it as practiced by Meinecke; Georg G. Iggers and Karl R. Popper are two whose works are cited below. A contemporary of Meinecke, Ernst Troeltsch (1865-1923) did not hesitate to formalize his definition of historicism in Der Historismus und seine Probleme (Tubingen: Mohr, 1922), and while he does not give, nor attempt to give, views identical to Meinecke, he agrees that historicism has no precedent.

2 As late as 1928 , Meinecke was defending his conception of historicism against criticisms of its abstract and indistinct character by reference to a time-lag between sudden intuitive comprehension and reflective rational exposition. "How often has it not turned out that a glittering catchword [historicism], born of experience, develops unsuspected fruitfulness in that it promotes the unification of scattered individual phenomena into larger complexes. Clarification and delimitation, insofar as these are possible, can in such cases only follow gradually." This passage appears in the essay "Values and Causalities in History," translated by Julian H. Franklin in F. Stern's anthology Varieties of History (New York: Random House, 1956), p. 277 . 
3 Foundations of Modern Historical Scholarship (New York: Columbia University Press, 1970), p. 302. This is one of several conclusions drawn by Kelley from the extensive analysis of Renaissance philology in this volume.

${ }^{4}$ Jakob and Wilhelm Grimm approached the German fund of Volksleider and Märchen with very similar attitudes and intentions, as will be shown in the next chapter.

5 This sense of the uniqueness of each past event was an essential component of what Spengler called Faustian Culture (Decline of the West (New York: Knopf, 1980), Vol. II, pp. 26-27), and even such a dedicated critic of Spengler as Herbert Butterfield agreed that this is a crucial difference between western historiography and the historiography of ancient Mesopotamia and China. See his Origins of History (New York: Basic Books, 1981).

${ }^{6}$ Kelley, Foundations, p. 4.

${ }^{7}$ Karl Popper overstates this by making later German historicism both a cause and a consequence of ethical relativism. Beginning with the affinities between historicism and other forms of relativism, Popper ends by making them equivalent. The Poverty of Historicism (Boston: Beacon Press, 1957). A less polemic treatment is given by Georg G. Iggers in The German Conception of History (Middletown, Conn.: Wesleyan University, 1968).

${ }^{8}$ G. Huppert, The Idea of Perfect History (Urbana: University of Illinois Press, 1970), p. 166.

${ }^{9}$ Ibid., p. 181 .

${ }^{10}$ These connotations are explored by Georg G. Iggers in the work cited in footnote 7 above. Iggers avoids simplifying the complexities of historicism with an historicism $=$ relativism equation.

${ }^{11}$ The complete lack of a sense of anachronism is strikingly apparent in medieval German origin-myths. See F. L. Borchardt, German Antiquity in Renaissance Myth (Baltimore: Johns Hopkins Press, 1977). Peter Burke, in The Renaissance Sense of the Past (London: Edward Arnold, 1969) makes an awareness of evidence equally as important as the anachronistic sense. He also stresses that an interest in causation was crucial ( $p .1$ ). Burke points out that not all ancient cultures lacked a sense of anachronism, citing Horace and Lucretius to show that the Romans had it, while the Greeks and the Hebrews lacked it (pp. 138-141). Herbert Butterfield concurs that Hebraic 
linear history was more metaphysical than a development from the empirical sense of anachronism or of change (Origins of History, pp. 80-89).

${ }^{12}$ G. H. Nadel, "The Philosophy of History Before Historicism," in Studies in the Philosophy of History: Selected Essays from "History and Theory", ed. G. H. Nadel (New York: Harper \& Row, 1965), pp. 49-73.

13 F. L. Borchardt, German Antiquity, p. 314.

${ }^{14}$ In France, the historian and politician Francois Guizot established state-subsidized collection and publication of primary materials from the national archives. The resulting Documents Inedits began to appear in 1833 . In Germany, it was the progressive Prussian minister Baron von Stein whose influence ensured the establishment of the Momumenta Germaniae Historica. Its first volume was published in 1826.

${ }^{15}$ Most students of modern nationalism define "national identity" as a collective identity not necessarily having a political content. "Nationalism"is national identity which has taken on a definite political content. This is how these terms were used by Carlton J. H. Hayes. His seminal study Essays on Nationalism (New York: Macmillan, 1928) will continue to provide useful guidelines for the examination of modern nationalism. 
CHAPTER II

\section{NINETEENTH CENTURY NATIONALISM}

\section{INTRODUCTION}

The previous chapter sought to elucidate a view of historicism broadly defined. This chapter takes the opposite tack with regard to nationalism. Though a sense of national identity among the French and Germans began to emerge with the Renaissance, its development through four centuries is of less concern here than are its nineteenth century manifestations.

It was in the course of the nineteenth century that the sense of national identity took on those forms of thought and action which correspond to the meaning of nationalism today. ${ }^{1}$ It will be seen that while nationalism has been intellectualized, it has never been an intellectual concept, since at bottom nationalism depends on emotion at the expense of thought. This is the reason why nationalism is always prepared to suppress intellectual activity when such activity seems to threaten the "national interest. $" 2$

Nationalism is vastly more complex than can be suggested by a brief statement of its basic assumption. The phenomenon of nationalism manifested itself differently 
in France than in Germany, for reasons which will become apparent.

\section{FRENCH NATIONALISM}

The French Revolution of 1789 destroyed, at least for a time, monarchy in France. It also destroyed, in many French minds, the notion of the French land as the personal property of a king and the concept of the French people as his subjects. The impact of Revolution, both in France and elsewhere, was tremendous: a millennium of tradition had been overthrown in France in the space of a few months. Hans Kohn expresses it this way:

The French Revolution grew out of a feeling for the need of a total renovation of life and society. It was an event of universal impact and recognized itself as such. It thought of itself as a beginning, concluding a period of mankind, starting, like Christianity, a new chapter in the history of the world.3

The above citation deserves some discussion in the light of what French nationalism was in the years during and immediately following the Revolution, because its early form bears little resemblance to what French nationalism was to become after 1815 .

The Revolution attempted, and failed to achieve, "a total renovation of 1 ife and society." Yet the most eloquent of the revolutionaries were convinced that the Revolution was in the interests not only of the French, but of all mankind. Egalitarian principles were expressed as if 
they were universally valid; there was nothing specifically French about them. The Revolution made France the first continental nation-state, and effected this in the name of universal principles, assumed by those who espoused them to be the only rational choice for any people possessing sufficient rationality to recognize their value. ${ }^{4}$

The contention that egalitarian principles were universally applicable had to be modified when it was discovered, during Napoleon Bonaparte's regime, that not all of the other peoples of Europe were eager to cast their several traditions aside and discard their identities in an embrace of the universalistic slogans shouted in their streets by French soldiers. Napoleon's vision of a united Europe proved a destructive chimera which had underestimated the endurance of a traditional regionalism of associations and identities. The collapse of the French Empire in 1815 seemed to many to demonstrate, among other things, that universal principles not only were not universal, but had no place in international politics. Russian Emperor Alexander I's "Holy Alliance" protestations notwithstanding, the Congress of Vienna (1814-1815) made unusual concession to reality in that it recognized the diversity of national interests and attempted to balance them.

A generation of the French had expended themselves in striving to bring the benefits of the Revolution to the 
other peoples of Western Europe. These benefits had been rejected and the new French nation had been humiliated. Suspicions that it had been a mistake to "export" the Revolution led to the illogical conclusion that only the French were capable of comprehending the value of the ideals of 1789. After 1815, French nationalism began to turn inward and became exclusive: the French were superior to other Europeans because these other Europeans had refused to recognize the value of the principles for which the French nation had suffered so much. This line of thought was to predominate in nineteenth century French nationalism. To be French was not only to be different from other Europeans, it was to be better than other Europeans. This is not to imply that a "superiority complex" was a French monopoly, but to emphasize that, after 1815, French claims of superiority among Western Europeans were commonly "proved" by reference to the Revolution of 1789, and that "Frenchness" was defined in terms of the Revolution.

After an initial universalist phase, then, French nationalism assumed the nature of an identity principle. In this change J. L. Talmon has seen evidence of a tenacious European diversity:

The evolution of nationalism from a universalist ideology into the dogma of the absolute primacy of the dictates of national survival and greatness emphasizes once more the victory of traditional 


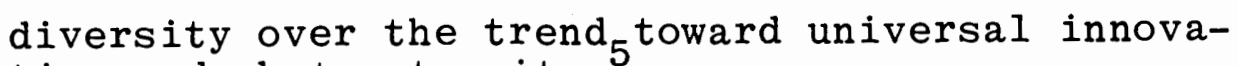
tion and abstract unity.

While French nationalism found its first expression within the context of abstract universal values and only became an exclusive identity principle after the collapse of 1815, German nationalism was from the first a search for "Germanness." In the interest of clarity it is useful to approach German nationalism in terms of a confrontation aptly formulated by Kohn:

Only the frame of a confrontation of the birth of a nation-state in France and the simultaneous attempts to create a German nation-state under the influence of the French Revolution and yet in opposition to it gives real meaning to the various and contradictory manifestations of nationalism. 6

\section{GERMAN NATIONALISM}

Many young and educated Germans recognized in the French Revolution a courageous attempt to accomplish the "total renovation" mentioned above. Joseph Görres (17761848) was one such idealistic young German. ${ }^{7}$ He hailed the passing of the old system of government in the Rhineland in satirical language. In the pages of his periodical Rotes Blatt (1797) Gorres announced the sale in Koblenz of three elector's caps of tanned buffalo-hide together with lead filled crosiers, furnished with daggers and encircled by artificial snakes. The eye of God mounted on the top is blind--two bishop's mitres, richly trimmed with tinsel, somewhat stained by cold sweat, but otherwise in good condition; hence very useful as red caps on trees of liberty-- A ducal hare skin hat, embellished with cock's feathers, trimmed with a precious stone distilled by a clever 
alchemist from the tears of ten thousand widows and orphans-- A barn full of patents of nobility, written on asses' skin, but badly motheaten in parts and giving out a strange smell of decay . . .8

The realities of French occupation soon caused Görres to doubt whether the revolutionary ideals he championed were being applied by the French. Between 1814 and 1816 Görres brought out another journal, the Rheinisher Merkur, in which he called on his countrymen to expel the French. More than that, Görres held forth in vague terms, sketching a united Germany with an emperor at its head. For Görres as for Herder, history was an organic process, and he sought to popularize a simplified version of Herder's Volk concept.

The work of Johann Gottfried Herder (1844-1803) was pregnant with ideas and concepts which were to be elaborated in literary romanticism and ethnic formulations of nationalism by the generations following him. His concept of Volk reflected a rejection of Enlightenment rationalism and universalism. Each Volk ("people" or "nation") was completely unique, and developed in an organic fashion much as each individual develops. Herder posited a "national spirit" or character (Volksgeist) which was the "personality" of the collective individual being, the Volk. This mean that no Volk was superior to any other, since it could be judged only in terms of itself. Though he apparently coined the term "nationalism," Herder's Volk concept did 
not involve politics at all, and is closer to present concepts of anthropology than to ethnic nationalism. A perceptive review of Herder's influence, particularly on Fichte, is given by Elie Kedourie, Nationalism (London: Hutchinson University Press, 1960).

\section{Die teutschen Volksbücher (1808) contains Görres'} truncated rendering of the Herder idea:

Each generation finds, provided it breaks out of its own chrysalis, that the flowers are already blooming and the sustenance already accumulated by those who have gone before, which it will develop in future metamorphoses, and nothing of it is lost. So our predecessors 9 and ancient ancestors live among us still. . .

In this sort of language Görres encouraged Germans to draw inspiration from their medieval past, when a strong German empire was a reality, and to use this inspiration to drive the French invaders from their land. In spite of Görres' vague style, the French censors recognized the veiled message and suppressed the Merkur.

Johann Gottlieb Fichte (1762-1814) made a similar turnabout in his attitudes. His Reden an die deutsche Nation (1807-1808) gave no hint that he had originally entertained sanguine hopes for the "new system" introduced into the German territories by the French.

Fichte delivered the lectures which form the Reden in Berlin to a very small audience consisting, ironically, primarily of French junior officers. In spite of the passages in which Fichte assigns to the German nation the 
premiere role in Europe, in ought to be remembered that the nation he addresses in the Reden was not a political state, but an idealized Kulturstaat conceived by Fichte as the protector of all the activities of the German people. The leading role he envisioned for Germans in Europe was not one of political and military power, but one based on their realization of the highest development of humanity, which meant for Fichte individual freedom.

Fichte is often interpreted as a "prophet" of nationalism, ${ }^{10}$ but if he was a prophet of anything it was of an optimistic positivism. His uncompromising idealism and faith in the cumulative improvement of humanity was much closer to later positivism than to the shaping of a collective identity in terms of the nation-state. Though, like Görres, he drew back from an initial uncritical welcome of the French Revolution, Fichte did not lose sight of the promise of 1789 as did Görres in his later years. The service of those unrealized ideals was Fichte's chosen work, and not practical politics. In fact, Fichte's reputation in Germany declined for a time after the War of Liberation because the Reden were deemed not "patriotic" enough. 11

It was philosophy, after all, that was Fichte's vocation. In the exercise of it he had, some years before the lectures in Berlin, exerted a powerful influence on a group of younger writers in Jena. This influence is unmistakable 
in the work of those writers called "early romantics," among them August Wilhelm and Friedrich Schlegel, Ludwig Tieck, Friedrich Wilhelm Schelling, and Friedrich von Hardenburg, who took the pen-name Novalis. Fichte's legacy belongs to philosophy and German literature more surely than to narrow nationalism, since even the Reden are a plea, not for a German nation-state, but for the eventual liberation of mankind from all that divides it, including the politics of the nation-state.

Hans Kohn and Golo Mann agree that Görres and Fichte were cosmopolitan rather than nationalists. They came to advocate the expulsion of the French because they were convinced that the French, under Napoleon, had betrayed their own revolutionary ideals.

The reaction of Friedrich Ludwig Jahn (1778-1852) to the French occupation was quite otherwise, and it is to Jahn that one must look for an early expression of the "Teutomania" which would typify extremes of German nationalism during the nineteenth century.

Jahn is best known as a result of his Spartan view of physical culture. He founded, during the years of occupation, the Turnverein, and in so doing introduced an element into German life which is still very much present today. Thoroughly anti-intellectual, Jahn's views are not difficult to portray. He simply hated foreigners and all foreign influences. Presumably he had taken this position 
all through his life, but the French occupation presented him with an ideal opportunity to act on his convictions. According to Jahn, the German imitation of French culture during the eighteenth century had weakened the German moral fiber. It was always a mistake for any people to be influenced by foreign ways, and by French ways especially. The French were effeminate and indecisive; they were treacherous and their manners were degenerate. The unwary Germans had assimilated some of these traits because the German character was naturally simple and trusting, "manly" and straightforward.

Jahn's xenophobia was linguistic as well. He regarded French as a bastardized Latin, while German constituted an Ursprache, a language remaining close to its earliest forms of expression. ${ }^{12}$ Jahn saw the adoption of French words and phrases as an abomination and demanded that German be "cleansed" of its foreign borrowings. Speech, as well as the body, must be purified. ${ }^{13}$ The Turnverein was immediately popular and spread throughout the German territories. It is often forgotten that modern gymnastics had its origin as a means of preparing youth for military service and as a vehicle for the dissemination of xenophobic nationalism.

Jahn expanded the Turnverein concept after 1815, applying it to academic life. German university students traditionally formed associations based on the region of 
their origin. Jahn's Burschenschaften were open to all students from German territories. They affected what Jahn conceived as "medieval" dress and used archaic forms of greeting.

The political implications of Jahn's Burschenschaften were not long in surfacing. Jahn was one of the organizers of the Wartburg Festival of 1817, which was scheduled to celebrate the anniversary of the Leipzig victory (October 28) and the tercentenary of the Reformation at the same time. Jahn was determined that his Burschenschaften, which had by this time spread from Jena to other universities, should be in the forefront of the proceedings. He was not disappointed. In their "medieval" costumes, Burschenschaften members from throughout the German territories burned copies of both the absolutist political philosophers and of Napoleon's Code Civil. They cheered for a united and democratic nation-state.

Jahn's fortunes took a bad turn after the assassination of Kotzebue in 1819. He was briefly imprisoned as a result of a tenuous connection between the assassin and a Burschenschaft group. 14

August von Kotzebue (1761-1819) was a mediocre playwright with a reputation as a defender of the reactionary policies against which the Burschenschaften demonstrated. He was also reputed to be an informant for the Russian 
tsar, which was more than enough to damn him in the eyes of the radical republican students.

Karl Sand was apparently unbalanced to the degree that he determined to act on the ideas of Karl Follen, a young lecturer at the University of Giessen. In the interests of the "higher morality" of a unified republic of Germany, Follen urged, conventional morality ought to be set aside. Sand took Follen at his word and stabbed Kotzebue to death in Giessen.

The proceedings against Sand, Follen, and other radicals created a scandal that served to link the Burschenschaften with terrorism and anarchy in the popular mind, and presented Metternich with an ideal opportunity to press into law those repressive measures known collectively as the Karlsbad Decrees. These went into effect in September of 1819 , just six months after the murder of Kotzebue, and they were temporarily effective in destroying any organized opposition to a status quo in which criticism was not tolerated.

Though the Karlsbad Decrees outlawed the Burschenschaften, their nationalistic and liberal ideals were preserved in numerous "clubs" and "study groups." The red, black and gold of the movement's Jena chapter came to symbolize opposition to Metternich's absolutist regime, and were the colors adopted at Frankfurt in 1848. 
Görres and Fichte have been contrasted with Jahn in order to bring out a distinction essential for an understanding of nineteenth-century German nationalism. Görres and Fichte came to object to French occupation only because it seemed to them that the French were proving themselves incapable of fulfilling the ideals of 1789, and they opposed the French on behalf of those universal ideals. Their being German was of secondary importance to them. But Jahn had never accepted anything from France. He derided abstract principles and the experiments made in the name of abstract principles. The concrete and the physical were all with Jahn. ${ }^{15}$ Germans were the most numerous Urvolk in Europe; it was therefore incumbent on them to make every effort to preserve their ethnic and linguistic purity from contamination by foreign elements. Jahn is often referred to as the "father of gymnastics," but the student of nationalism must also recognize in Jahn a progenitor of an extreme form of nineteenth-century German nationalism. His simple message appealed to the emotions, and reached the masses of the German people in a way that the more sophisticated thought of Görres, Herder, and Fichte could not. 16 


\section{THE SYMBIOTIC RELATIONSHIP OF FRENCH}

\section{AND GERMAN NATIONALISM}

After the prostration of France in 1815, French nationalism discarded its initial universalist character and assumed the nature of a definition of "Frenchness" in which the French were the superior people of Europe if not the world. In the German territories, men such as Görres and Fichte did much to mobilize German sentiment against the occupying French. But the cosmopolitanism of their message was unable to achieve as great an effect as did the virulent xenophobia of men such as Jahn, who elaborated a partly linguistic, parly physiological definition of "Germanness" in which the Germans figured as the superior people.

In general terms, the French felt themselves to be whatever the Germans were not, and vice versa. To a very great degree, each group defined itself in terms of the other. The French prided themselves on their sophistication and refinement; the Germans on simplicity and frankness. The fact that such traits on the collective level are of more a mythic than an empirically verifiable character only safeguards them from realistic qualification. Though many Frenchmen were neither sophisticated nor refined, many Germans complex and subtle, it remained a matter of faith during the nineteenth century that the 
ideal Frenchman was suave and the ideal German was forthright. Why were such contrasts sought and found in all types of human activity and all forms of human expression? Obviously, they were irresistible simplifications which served to reinforce the collective identity of each national group by means of the projection of traits defined as negative onto the other group. In a very real sense, each group depended on the other for its own self-definition, as is especially apparent in the case of Jahn.

The nation-state requires a definition from its citizens in relation to itself which in its simplest, most accessible form is primitive group pride and xenophobia. Hatred and suspicion of the "other" nourishes group solidarity, but makes that solidarity depend, ultimately, on the existence of the "other." It is a symbiotic relationship insofar as each group makes use of the other to define and reinforce its own identity.

Throughout the nineteenth century mutual French and German xenophobias faced one another across a lengthy common frontier. Both "Frenchness" and "Germanness" had their origins in the French Revolution and its drawn-out aftermath, and each defined itself to a great extent in terms of the other. French and German nationalism interacted in a symbiotic relationship which is also evident in the interrelation of French and German 
romanticism. Though both French and German artists participated in a common cultural phenomenon known as the "romantic movement," the participation was, in many cases, a means for the further elaboration of definitions of "Frenchness" and "Germanness." 


\section{NOTES: CHAPTER II}

\section{$1_{\text {The International Encyclopedia of the Social }}$} Sciences ${ }^{\dagger}$ (ed. David L. Sills (New York: Crowell, Collier and Macmilian, 1978)) definition is by Hans Kohn: "Nationalism is a political creed that underlies the cohesion of modern societies and legitimizes their claim to authority. Nationalism centers the supreme loyalty of the overwhelming majority of the people upon the nation-state, either existing or desired. The nation-state, is regarded not only as the ideal, 'natural' or 'normal' form of political organization but also as the indispensable framework for all social, cultural, and economic activities." Kohn's conception of nationalism is concentrated on its political content, i.e., as a pre-existent national identity mobilized in the interest of the nation-state. George L. Mosse defines nationalism in terms of the psychological appeal it usually possesses: "Nationalism [promised] a happy and healthy world protected against the rush of time... Nationalism promised to restore order and the respect for immutable values, and to maintain clear distinctions between the accepted and the unacceptable-- lines upon which men and women could model their life to escape confusion." (Masses and Man: Nationalistic and Fascistic Perceptions of Reality (New York: Howard Fertig, 1980), p. 1) While the Kohn and Mosse definitions are generally followed in this story, anyone attempting to understand the complexities of nationalism and the varieties of its definition ought to be aware also of the multitude of studies available. The following list represents only a small sample. The works of Carlton J. H. Hayes are classics in terms of neutral definition of nationalism, as are those of Boyd C. Shafer. (See Bibliography.) Negative evaluations of nationalism are given by Edward H. Carr (Nationalism and After (New York: Macmillan, 1943)) and Karl W. Deutsch (Nationalism and Its Alternatives (New York: Knopf, 1969)). General studies of European nationalism in German are offered by Waldemar Mitscherlich (Nationalismus: Die Geschichte einer Idee (Leipzig: Schwab, 1929)) and Eugen Limberg Geschichte des Nationalismus in Europa (Leipzig: Hirschfeld, 1951)). Three valuable general treatments in English are given by Elie Kedourie (Nationalism (London: Hutchinson University Press, 1960)), H. Munro Chadwick (The Nationalities of Europe and the Growth of National Ideologies (New York: Cooper Square, 1945)), and in an anthology edited by Eugene Kamenka 
(Nationalism: The Nature and Evolution of an Idea (New York: St. Martin's Press, 1976)). The last work contains essays on Asian and Middle Eastern nationalism as well.

${ }^{2}$ H. Munro Chadwick laid great stress on the primitiveness of the bases of patriotism and nationalism, which he called "primary feelings" and which he regarded as "natural" (Chadwick, Nationalities of Europe).

${ }^{3}$ Hans Kohn, Making of the Modern French Mind (Princeton: D. Van Nostrand Co., 1955), p. 12. Kohn's positive evaluation of this "renovation" may be balanced by the Christian critique of revolutionary millenarianism and the Jacobin Cult of the Supreme Being given by C. H. Dawson in The Gods of Revolution (New York: New York University Press, 1972).

${ }^{4}$ Carl Becker demonstrated over fifty years ago that the Enlightenment did not "abolish" faith in Christianity, but substituted for it a no-less religious faith in human perfectability (The Heavenly City of the Eighteenth Century Philosophers (New Haven, Conn.: Yale University Press, 1932)).

5 J. L. Talmon, Political Messianism (New York: Praeger, 1960), p. 50. Talmon is speaking of nationalism in general in this passage, but the remarks are especially relevant to the evolution of French nationalism.

${ }^{6}$ Hans Kohn, Prelude to Nation-States (Princeton: D. Van Nostrand Co., 1967), p. vi.

7 Like others of his generation, Görres made the pilgrimage from rebellious nonconformity to Catholic conversion on the personal level and from Jacobinism to reactionary conservatism on the political. He first became critical of his initial welcoming of the Revolution to German territory as a result of interaction with Achim von Arnim and Clemens Bretano in 1808. Through them, Görres met other writers of the romantic movement, and it was in emulation of Arnim and Bretano's Des Knaben Wunderhorns that he produced, with help from Bretano, Die teutschen Volksbücher. His dedication to the cause of political unification drove him to Strasbourg after passage of the Karlsbad Decrees in 1819, but in later years he made his peace with the status quo, accepting an appointment from Ludwig I of Bavaria as professor of history in Munich. At the time of his death on the eve of the March Revolution of 1848, Görres' philosophical and political position was nearly the opposite of the views he had once expressed in Das rotes Blatt. 
${ }^{8}$ Quoted in G. Mann, History of Germany Since 1789 (New York: Praeger, 1968), p. 24.

${ }^{9}$ p. Kluckhohn, Hrsq., Deutsche Vergangenheit und deutscher Staat (Darmstadt: Wissenschaftiche Buchgesel1schaft, 1964), p. 130. My translation.

${ }^{10} \mathrm{~K}$. R. Minogue can view the Reden as evidence of nothing else but nationalistic bombast, and opines that the Reden display a "morbid sensitivity to the opinion of foreigners" (Nationalism (London: Jarrold and Sons, 1967), p. 65). Minogue has Fichte reacting to feelings of German inferiority with claims of German superiority.

\section{${ }^{11}$ This is brought out by H. C. Engelbrecht in the} concluding chapter of Johann Gottlieb Fichte: a Study of His Political Writings With Special Reference to His

Nationalism (New York: Columbia University Press, 1933), as added emphasis of the preponderance of idealism and cosmopolitanism in Fichte.

$12 \mathrm{Jahn}$ restated Herder's concept of a unique language as a necessary element of a Volk in cruder and more forceful terms, and gave the same treatment to Herder's idea that each Volk, in order to ensure the survival of its own unique identity, ought to avoid wholesale and incautious "borrowing" from other Volker. While Jahn's xenophobia reflects certain of Herder's ideas taken out of context and pushed to their logical conclusions, the fanaticism of Jahn would have been extremely repugnant to Herder, who was as much an Enlightenment philosophè as a German intellectual fascinated by Volk und Blut conceptualizations of world history. Herder's self-image as an enlightened "worldcitizen" first and a member of the German Volk second is very evident in his private correspondence. See the collection by Hans Reisinger, Johann Gottfried Herder: sein Leben in Selbstzeugnissen, Briefen und Berichten (Darmstadt: Wissenschaftliche Buchgesellschaft, 1970). The philology of the Grimm brothers gave support to Jahn's belief that German was closer to the hypothetical IndoEuropean Ursprache than any other extant language. The Grimms' speculations on this seminal Ursprache can be found in their Deutsche Sagen and Deutsche Mythologie.

${ }^{13}$ Again, Jahn was echoing, in tones much louder and more roughly executed, sentiments on this subject voiced by subtler intellects. Herder has already been mentioned. The playwright and theologian Gotthold Ephraim Lessing (1729-1781) ridiculed affected French fashion and manners in the comedy Minna von Barnhelm (1767). In the Sturm und Drang phase of his career, Goethe (1749-1832) took the same 
tack, in Gotz von Berlichingen (1773) imitating the "rustic" style of Shakespeare to pointedly violate the classical forms of theater borrowed from Corneille and Racine. Friedrich Schiller (1759-1805) was another who sought to defend all things German from "Frenchification" by celebrating the expressive capacities of German language. In his Wallenstein (1799) and Wilhelm Tell (1804) the attempt was made to use archaic forms and expressions assumed by Schiller to be appropriate to the periods portrayed. But none of these men took the farther step into Ursprache theorizing about the hypothetical original common language of Western Europe.

${ }^{14}$ Schleiermacher was another who came under suspicion. His sermons were closely monitored, due to his praises of the Burschenschaften.

${ }^{15}$ It has been mentioned that he designed the "medieval" Burschenschaften dress. He also designed a gymnastic outfit conforming to his ideas of classical Greek attire. On the linguistic front, Jahn insisted that gymnastic meetings held in a meadow would designate that spot a "tie," a name given to ancient German meeting places. This in George L. Mosse, The Nationalization of the Masses (New York: Howard Fertig, 1975), p. 128.

${ }^{16}$ Meinecke demonstrates how interrelated were nationalism and universalism in the thinking of Fichte and the romantic writers Novalis and the Schlegel brothers (Weltbürgertum und Nationalstaat). It is important to remember that for Herder and Fichte the only genuine or "organic" state was a Kulturstaat, a state fostering the arts, education, and individual self-improvement for its citizens, and not a political Machtstaat based on military power. As Meinecke points out, the cosmopolitan sentiments voiced by Herder, Fichte, and most of the romantics seemed to be discredited in Germany after 1848, and this made it possible for Bismarck to be viewed as a "liberator" through his discounting of idealism and his working definition of the state as Machtstaat. In this view, Bismarck "liberated" Germans from impractical political idealism by compelling them to take a more "realistic" approach to the state. 
CHAPTER III

\section{ROMANTICISM IN FRANCE AND GERMANY}

\section{INTRODUCTION}

The lowest common denominator of that myriad of phenomena which have been placed under the rubric "romanticism" is a view of life which sets the urgings of the heart above the counsel of the head. Such a view may assume various forms, ranging from casual attitude to systematic philosophy, but all of the forms of romanticism have one characteristic quality: in the continual conflict of spontaneous emotion with cautious rationality, romanticism is the champion of emotion. ${ }^{1}$

When this simple but quintessential definition of romanticism is applied to a review of European history, it becomes apparent that various "romantic" individuals and "romantic" movements are scattered throughout the record. ${ }^{2}$ It is a mistake to define romanticism only in terms of its nineteenth century context, since such a definition tends to overlook the obvious: that romanticism originates in the human condition itself, rather than in an individual's political and cultural environment. National politics and national identity certainly 
influenced the forms of nineteenth century romanticism, but its essence was uniform in all of the nations of Europe. ${ }^{3}$

This last point is a crucial one. Scholars like Furst, who are specialists in the field of literature, have expended much effort in isolating the external forms of romanticism with the purpose of identifying several national "schools." There has been a confusing abundance of analysis and an unfortunate dearth of synthesis, even on the part of some scholars who have attempted to survey the movement as a whole and to relate the national variations of romanticism to one another. ${ }^{4}$

In its nineteenth century manifestations, romanticism was a reaction to the classicism of the preceding century. Eighteenth century classicism had demanded rationality of the arts; had valued a stylized expression over emotional expression. Perhaps the most useful definition of nineteenth century romanticism is that it was the effusive expression of what the classical aesthetic had denied. 5 N. H. Clement offered this inventory of romanticism:

It is a return to the Middle Ages, not only for subjects, but in a measure for its spirit. . . it is melancholy brooding and love of solitude; it is morbid introspection and self-analysis; it is a yearning after remote places and times . . . Of these aspects of romanticism, the "return to the Middle Ages" is of particular concern in the following pages. It was a sentiment having wide currency among both the French and German romantics. 
While a yearning for the Middle Ages was an element of romanticism first appearing in the nineteenth century, the "noble savage" concept had had a long career. In Chapter IV the working of this theme by Tacitus in his Germania will be reviewed.

Nostalgia for the Middle Ages and the cult of the noble savage were to merge, with peculiar results, in the writings of several French and German romantics. Novalis, as a representative of German romanticism, will be considered first, since the preoccupation of the German romantics with the past preceded that of their French counterparts.

\section{GERMAN ROMANTICISM}

It was observed above that much of the study of romanticism has gone into the dissection of the general movement and the intensive analysis of its various national "schools." The merit of this undertaking has been to demonstrate the complexity of the movement in terms of its external forms. 7 The trouble with such an approach is that it is often based on, or calls for, certain generalizations concerning national character which must be treated with extreme caution by the careful student.

Peter Viereck's Metapolitics: The Roots of the Nazi Mind is a classic exposition of the distortions produced when a cultural historian insists on viewing the past in 
terms of the present. Viereck saw in romanticism not a European but a uniquely German cultural phenomenon, and Metapolitics represents an attempt to make romanticism synonymous with "proto-Nazism." For Viereck, the Nazi movement is only the most recent installment of romanticism; romanticism thus becomes a threat to the entire "western heritage":

Romanticism is typically "Germanic" in its broadest versions . . . one may treat romanticism as a cultural and political reaction against the Roman-French-Mediterranean spirit of clarity, rationality, form, and universal standards. Thereby romanticism is really the nineteenth century's version of the perennial German revolt against the Western heritage. ${ }^{8}$

That Metapolitics was first published in 1941 may perhaps explain its caricature of one phase of German culture, but it does not excuse the confusion the book can create in those of its readers unprepared to critically evaluate Viereck's conclusions. His documentation gives no hint of the varieties of the cultural phenomenon he is supposedly analyzing, but abounds in references to the Schopenhauerian maunderings of Richard Wagner. Viereck also did not, or did not care to, realize that an aphorism is not to be understood literally: a caveat that is indispensable when coping with the aphorisms of Friedrich Nietzsche. In the following discussion of Novalis and German romanticism an historicist approach will be used. He will be viewed, so far as is possible, within the 
context of the late eighteenth century, and his Christenheit oder Europa will be examined not on the basis of subsequent criticism, but in terms of that essay itself.

FRIEDRICH VON HARDENBURG (NOVALIS) (1772-1801)

Novalis chose his pseudonym from a thirteenth century branch of his family (de Novali). This identification with the Middle Ages testifies as surely as anything he wrote to his particular form of romanticism.

In 1792, while studying law at Leipzig, the young Hardenburg made the acquaintance of several other young men who were later to be called romantic writers. For instance, he met Friedrich Schlegel there, and was to maintain a lifelong friendship with him. It was under the influence of the Schlegel brothers and their friends, Fichte and Ludwig Tieck among them, that Hardenburg adopted the name Novalis. 9

Novalis did not devote all of his time to writing. From 1794 until his death in 1801 he was engaged in one or another aspect of salt mining in Saxony. In the summer before his death, Novalis led a geological survey which was one part of a comprehensive study of the whole of Saxony masterminded by Abraham Gottlob Werner, under whom Novalis had studied "neptunist" geology at the Freiberg Mining Academy in 1798. Novalis appears to have been a dedicated and capable civil servant; an aspect of his life which is 
often ignored in the usual depictions of him as an idle and withdrawn dreamer. ${ }^{10}$ The image of Novalis as a man at odds with reality was largely the creation of his posthumous editors, Friedrich Schlegel and Ludwig Tieck. ${ }^{11}$

The poems of Novalis are introspective and often concerned with death as a liberation from worldly grief and care. This may in part be explained by the emotional devastation he experienced at the deaths (1797) of his young fiancée Sophie von Kühn and his younger brother Erasmus, but the subjective quality of his poetry also unmistakably proceeds from a sense of not "belonging" to contemporary culture, of being, in the common phrase, "born too late." Novalis would rather have been born in the Middle Ages.

The roots of this feeling of being somehow misplaced in time are displayed by Novalis in the prose essay Christenheit oder Europa, written in $1799 .^{12}$ It will become apparent that this essay may also be viewed as virtually a manifesto of a romantic idealization of the Middle Ages which will be encountered in the works of later romantics, both German and French. 13

Novalis contrasts an idyllic vision of medieval Europe with the reality of the present Europe, and, predictably, finds the present reality wanting. For Novalis, the Middle Ages were a time of unity and order, while contemporary Europe (and not just for Novalis) seemed a 
time of fragmentation and disorder. The medieval "unity" and "order" seen by Novalis existed only in his own imagination, but it struck a responsive chord among his literary friends. (Christenheit oder Europa was not published until 1826, but circulated after his death in manuscript.)

In short, Christenheit oder Europa offered an historically inaccurate interpretation of the Middle Ages which was particularly appealing to those who had become disillusioned by the apparent failure of the secular ideals of the French Revolution. ${ }^{14}$ Only religious values can be universal. The only hope for Europe, as Novalis saw it, was in a rejuvenated Christianity. This reborn Christianity was not not be a revival of Catholicism, but a Christianity remodeled along the lines of the German Pietism in whose atmosphere Novalis had matured. ${ }^{15}$ Men's faith in secular values had ruined Europe: it was time for a return to the values of religion, which alone were of any universal significance.

Novalis made no explicit reference to the noble savage, but the concept is implicit in Christenheit oder Europa nevertheless. The medieval man, whether king or peasant, is a noble savage in comparison to the eighteenth century European man. The medieval woman is either a Mary or a Mary Magdalene when contrasted with her refined contemporary sisters. The Middle Ages were for Novalis a 
time when Europeans were closer to the supposed ideal state of nature. Their emotions were simple but strong, their manners crude but having a grace which is lost through sophistication. These are essential characteristics of the noble savage persona.

The political implications of Christenheit oder Europa amount to a conservative posture of wait-and-see. Flaws in the status quo were not overlooked, but were not seen as hindrances to the eventual establishment of the New Jerusalem, which political action could neither hasten nor delay. ${ }^{16}$ This was to be the standard approach of the German romantics to politics, and is one of their points of difference with the French romantics. Though none of the German romantics wrote on specifically political topics, their literature often has political implications. These implications are generally conservative. It was left to the next generation to link literature to the cause of liberal reform in a movement known as "Young Germany."17 Novalis is a representative of German romanticism even though he is classified as an "early" romantic associated with the "Berlin-Jena school" (as opposed to the "Heidelberg school"), and in spite of the fact that he was not widely read during his lifetime. Novalis is perhaps the best representative of German romanticism because his frequently formless and mostly unfinished writings contain, in full bloom or in germ, virtually all of the themes which 
were to be developed by later romantics. ${ }^{18}$ His rose-tinted vision of the Middle Ages was given a slightly more vivid focus in Achim von Arnim's Die Kronenwachter (1817), and the destruction of the legions of Varus was dramatized by Heinrich von Kleist in Die Hermannschlacht (1808). In the Kleist drama Arminius is portrayed as a noble savage whose native cunning permits him to outwit the over-refined Roman professionals. Many more examples might be given to demonstrate the development in German romanticism of themes found in Novalis. In some cases, the link with later writers was also personal. Ludwig Tieck was one of Novalis' closest fellow-writers, and lived on until 1853. He was idolized by part of the younger generation, among whom was Gustav Freytag, who corresponded with Tieck, and who was to further elaborate the romantic definition of German identity. 19

Novalis provided a vision of the Middle Ages which proved to be seminal for romanticism in general and for German romanticism in particular. This vision, however, was a reaction to contemporary political reality, and the disillusion experienced by Novalis was shared by others throughout Europe. Francois Chateaubriand was the French counterpart of Novalis. Like Novalis, Chateaubriand turned his back on contemporary culture and politics in his search for values and ideals more substantial than those of 1789 . 
It will be seen that Chateaubriand arrived very nearly at the same destination in his search as had Novalis a few years before him.

\section{FRENCH ROMANTICISM}

The French manifestations of romanticism have not suffered the distortions which have plagued German romanticism since the Hitler era. This is no doubt in part because French fascism has never captured the world's attention as did German fascism. French romantic artists have been spared the search for proto-fascists in their midst.

Victor Hugo (1802-1885) commonly comes to mind when French romantic writers are mentioned, and French romanticism is associated in a casual manner with liberal politics and the cause of social reform. Les Miserables is probably Hugo's best-known novel among English readers, yet it appeared in 1862, and can only represent a late phase of its author's development. Hugo's early work, pre-1830, was strongly royalist and intensely Catholic. Stated briefly, Hugo began his career as a reactionary and ended it as a liberal. 20

Hugo's career mirrors that of the French romanticism of which it is one part. In the years after 1815 romantic writers played a considerable role as apologists of the Restoration and of Catholicism. It has been stressed above 
that romanticism was basically a rejection of classicist rationality. Not surprisingly, the first phase of romanticism in France was characterized by an assault on religious skepticism.

In its first phase, then, French romanticism was essentially identical to German romanticism. It will be demonstrated below that Novalis and Chateaubriand, though differing as to what was the most valuable form of Christianity, were agreed that a reliance on secular values was what was wrong with their Europe.

What distinguishes French romanticism is the transition made by most French romantics from conservatism to liberal or even "leftist" viewpoints in the years immediately preceding or following the Revolution of 1830 . Several French romantics were actively involved in public affairs (Francois Chateaubriand, for instance, who resigned a minor governmental post in disgust at the Napoleonic regime). German romantics, with rare exceptions (of which Eichendorff was one), tended to remain observers, and usually indifferent observers, of politics. It is not an exaggeration to view the German romantics as remaining closer to the original impulse of romantic sentiment than did the French. The Germans were from the first occupied with self, and continued in this self-absorption. 21

It might be said that French romantics possessed what is today called a "social conscience." What is undeniable 
is that most French romantic writers felt a compulsion to educate their readers in one way or another. A didactic tone is typical of French romanticism in both its early and later phases, but was more pronounced in the pre-1830 period. Chateaubriand gave the first French rendition of a romantic solution to the ills of his contemporaries.

\section{FRANCOIS CHATEAUBRIAND (1768-1848)}

Chateaubriand's first political sympathies were royalist. He was among the émigrés of 1792. After the "alliance" between Bonaparte and the papacy established by the Concordat of 1801, he returned to France but found he could not adapt himself to the new regime, though he gradually moderated his royalist sentiments to the extent of welcoming the institution of a constitutional monarchy provided by the Charter of 1814. He viewed the Revolution of 1830 as unfortunate and hoped that it would not lead to further "excesses." Chateaubriand's politics underwent change through the years, as did his religious convictions. After his mother's death he "rediscovered" the traditional Catholicism in whose influence he had been reared, and his two best-known works are an expression of his religiosity. 22

The return to the Middle Ages urged in Génie du Christianisme (1801) and Les Martyrs (1814) is much more subtle than that found in Novalis, yet a medieval nostalgia 
pervades these two essays in much the same way that the noble savage persona is implicit in Christenheit oder Europa.

In Génie Chateaubriand employs arguments based on the romantic sensibility in the defense of Catholicism. Christian apologetics had a long tradition, but Chateaubriand infused a romantic element into this old genre in an attempt to appeal to his readers through their emotions and aesthetic sense. In this he is the French counterpart of Novalis. Both men were working romanticism in the service of religion. Beyond this, however, the similarity breaks down.

The Christianity of Novalis was a vague sort of reformed Protestantism, but for Chateaubriand Christianity equals Catholicism, and especially Catholicism as he believed it once existed in France. Moreover, the Génie and Les Martyrs are the work of a publicist; they are intended to be widely read and discussed, and they were. There was nothing of the publicist about Novalis. His writing was a personal and private affair.

In Génie Chateaubriand defends Catholicism from its skeptical detractors on the grounds that it is beautiful, that it evokes beautiful emotions in the believer. Just as Christianity is more poetic than other religions, Catholicism is the most poetic form of Christianity. It ought to be embraced just because of its poetic beauty. Rationality, 
duty, and traditional theology are for Chateaubriand insufficient to sustain a true Christian faith. Faith needs to root itself in emotion, where it cannot be assailed by rational skepticism of the sort made fashionable by the philosophes.

One of the contentions in Génie is that Christian hagiography is superior in poetics to anything that the themes of classical mythology can offer. Les Martyrs is Chateaubriand's attempt to prove this contention. Whether the attempt is successful is of less moment here than the idealized view of the Middle Ages implicit in this work.

It is the same view one finds in Novalis. The medieval centuries are the "good old days" not necessarily because they are old, but because they were good. Chateaubriand, Novalis, and Schliermacher were agreed that at no other period had Christian belief assumed such purity and sincerity of expression, and that the hope of Europe's future lay in a return to that ardent but innocent faith.

Chateaubriand wrote romantic apologetics and romantic hagiography in which medieval nostalgia plays a prominent role. He also wrote novels in which the noble savage persona is an essential element. Atala (1801) bestows on the American Indian all of the virtues Rousseau had attributed to humanity prior to the drawing up of that fatal social contract which was to end all innocence. While it perhaps need not be stressed that Chateaubriand would not 
have uttered the words "saint" and "savage" in the same breath, Atala is evidence that he believed there was something "saint-like" about the American aborigines. Les Martyrs expressed this belief conversely, by implying that the saints of the medieval Church were in effect the noble savages of Christianity in the innocence of their faith and the strength of their commitment.

\section{CONCLUSION}

The most meaningful distinction between French and German romanticism is to be seen in differing orientations. French romantics were generally interested in directly attempting an improvement of society, while to the same end the German romantics expended most of their energy in selfexploration and introspection. These generalizations must be applied by the careful student with an awareness of their limitations however, and attempts to arrive at a definition of "Frenchness" or "Germanness" based on the generally direct public orientation of French romanticism and the generally personal nature of German romanticism ought to be avoided.

Only a refusal to view the German romantics in terms of the historicist approach can explain Viereck's portrayal of them as "proto-Nazis." Those scholars who assert that the espousal of liberal reform on the part of many French romantics was a function of the central position of some 
definition of "Frenchness" within a tradition of representative institutions and personal liberties which usually goes under the name of the "western heritage" are making an identical error. 23

German romanticism is properly understood as a continuation of the tradition of medieval and Renaissance mysticism, which was, in terms of romanticism broadly defined, a "pre-romantic" romanticism. It may also be useful to regard the more public orientation of French romanticism, especially after 1830 , as a result of a literary centralism rather than as a comment on French national character. The political fragmentation of the German territories precluded the formation of a reading public as it existed in the France of Chateaubriand and Hugo, where the dominance of Paris set the fashion in literature as well as in all other aspects of life. That a potential reading public also existed in Germany is indicated by the career of Görres. In examining the differences between French and German romanticism, it ought to be remembered that romanticism in the nineteenth century was a movement effecting all of Europe. The French and German romantics had perhaps more in common than they themselves would have been willing to admit; both idealized the Middle Ages and both elaborated the noble savage persona.

Imperial Russia was not immune to romantic idealizations of the medieval period or to the stirrings of 
nationalism provoked by the resistance to Napoleon. Peter Chaadaev (1794-1856) wrote the first of seven Letters on the Philosophy of History in 1829 and finally published it in the Moscow journal Teleskop in 1836. It soon became a gospel to the "Westerners." Chaadaev argued the superiority of Catholicism over Greek Orthodoxy on the basis of their respective accomplishments. Orthodoxy had produced nothing to compare with the medieval culture of Western Europe, in Chaadaev's view. Russia's Middle Ages were a wasteland which held nothing worth serious study.

Refutations of Chaadaev's "Westerner" interpretation of the Russian Middle Ages and Russian culture in general were not long in coming, one of the most persuasive being from Ivan Kireevskii (1806-1856). His On the Nature of Russian Culture and Its Relation to the Culture of Europe (1852) used the Herder and Fichtian concept of organic development to defend Russia's unique characteristics. Kireevskii went much further, however, and proclaimed Russia's superiority to the West on the grounds of the "uncorrupted simplicity" of its Orthodoxy and a decidedly romantic rendering of medieval Russian life and faith. Kireevskii came to be regarded as the spokesman of the "Slavophiles," whose running debate with the "Westerners" was characterized by nationalistic hubris and romantic views of history on both sides. Kireevskii's brother 
Peter was a student of native folklore and a collector of ballads. 24

It has been seen that romanticism was not confined to the arts. It was capable of being put to almost any purpose, and was particularly well suited to the recreation of the medieval past with a view to establishing the collective identity demanded by the upsurge of nationalistic feeling in the first half of the nineteenth century. This point is illustrated by the work of the Grimm brothers (Jakob and Wilhelm), whose researches were inspired as much by their romantic sensibilities as by any disinterested scholarly curiosity.

The brothers Jakob (1785-1863) and Wilhelm (17861859) were profoundly influenced by Tieck's Minnelieder aus dem swäbischen Zeitalter (1803), becoming fascinated with the possibilities of early German literature and folklore. Tieck's introduction to Minnelieder, a call for the recognition of a neglected folk heritage, was "hinreissend" (compelling) to Jakob Grimm. Edwin H. Zeydel maintains that it was under inspiration of the Minnelieder that he began studying the Bodmer collection. ${ }^{25}$ Jakob came to hold views of previous generations very similar to those found in the works of Novalis and Chateaubriand. He wrote to Achim von Arnim, another prominent folklorist, "Our ancestors were greater, purer, more pious than we; 
they still had in them and above them an aura of divine emanation." 26

Germanic legends are collected in Deutsche Sagen (1816-18); Deutsche Mythologie (1835) deals with ancient Germanic religion. Underlying these works are the assumptions elaborated by Herder and Fichte. The culture of each unique Volk develops in an organic manner which is reflected in its legends and collective beliefs. These are much more valuable to the Volk than academic history: "There is actually nothing that the folk can gain from what is called 'true history' . . that has not already been conveyed to them by means of the legend." 27

Convinced of the value of folklore, the Grimms (especially Jakob) approached them with a reverence partaking of the celebrated Waldeinsamkeit first conjured in Tieck's Der blonde Eckbert in 1797.

In regard to our legends, one must quietly lift the leaves and carefully bend back the bough so as not to disturb the folk, if one wants to steal a furtive glance into the strange yet modest world of nature, nestled into itself, and smelling of $\mathrm{fal}_{\overline{2}} \overline{8}$ len leaves, meadow grass, and fresh-fallen rain.

Though Wilhelm was more reserved, Jakob was prepared to see the ancient Germanic tribes as enjoying a freedom and spiritual purity since lost, and to which his liberal politics were to attempt a return. 29

The Grimms were determined that German language and culture (the terms were nearly synonymous for them) ought 
to be recognized among other peoples of Europe for their relatively "undiluted" character, and all of their efforts were directed toward this end. Jakob brought out a translation of the Germania of Tacitus in 1835, as a companionvolume to Deutsche Mythologie. In the Grimms one sees what may be called a cultural nationalism grounded on a romantic idealization of the ancient Germanic and medieval past.

Novalis and Chateaubriand wrote Christian apologetics; the Grimms' philological and folklore studies were at the same time exercises in romanticism and nationalism. Jules Michelet's ardent admiration of their work was one of the sources of a potent infusion of romanticism into the history of the French nation. 


\section{NOTES: CHAPTER III}

$1_{\text {This working definition was also used by Jacques }}$ Barzun (Classic, Romantic, and Modern (Garden City, N.Y.: Anchor Books, 1965)), who made "romanticism" first appear in the writings of Blaise Pascal.

${ }^{2}$ Conspicuous among romantics living before the nineteenth century are the Neo-platonists and the medieval heretics who stressed personal faith over formal observance; Francis of Assisi; Cretien de Troyes; and most of the Christian mystics, particularly the fourteenth century Beguine, Mechthild von Magdeburg.

${ }^{3}$ Lillian R. Furst disagrees with every point in this paragraph, but criticizes the generalization of a "panEuropean" romanticism for failing to take into account European cultural diversity and the complexity of the movement itself, rather than for neglecting the component of nationalism, which she also downplays. Romanticism (Vol. 2 of the Critical Idiom series, John D. Jump ed. (London: Methuen \& Co., 1969), pp. 65-66.

${ }^{4}$ Despite G. Brandes' attention to synthesis in his Main Currents of Nineteenth Century Literature, a palpable Danish and Protestant bias is always present, as well as a certain Victorian prudery. For instance, Friedrich Schlegel was for Brandes not much more than a "wastrel."

5 Furst also questions this statement and the preceding one, again on the grounds that such generalizations are of some help only to the beginning student of romanticism. Kenneth Clark defends the utility of such generalizations in The Romantic Rebellion (London: Harper \& Row, 1973). Nineteenth century forms of romanticism of course did not emerge full-blown at the turn of the century; classicism shades into romanticism. On this process, see J. G. Robertson, Studies in the Genesis of Romantic Theory in the Eighteenth Century (New York: Russell \& Russell, 1962), and M. B. Finch, The Origins of French Romanticism (New York: E. P. Dutton, 1920). Eighteenth century antecedents in Germany are examined by Helmut Schanze, Romantik und Aufklarung (Nuremburg: Hans Kohl, 1966), and Howard M. Jones discusses the "sensibility" movement in late classicism as a transition genre in Revolution and Romanticism (Cambridge, Mass.: Harvard University Press, 1974). 
${ }^{6}$ N. H. Clement, Romanticism in France (New York: Modern Language Association of America, 1939), p. 173. Clement refers in this passage to romanticism in general, in its admittedly general character as a "pan-European" phenomenon.

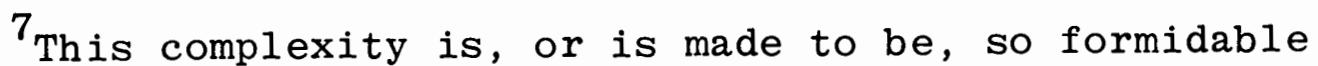
that an anthology of essays on the problem (Begriffstimmung der Romantik, Helmut Prang, ed. (Darmstadt: Wissenschaftliche Buchgesellschaft, 1968) concludes with a piece by Henry H. H. Remak which questions whether such a definition is either necessary or possible ("Ein Schlussel zur westeuropäischen Romantik?").

${ }^{8}$ Metapolitics (New York: Knopf, 1947), p. 19. The national socialist definition was identical, but with positive connotations. See Willi A. Koch's introduction to Briefe deutscher Romantiker (Leipzig: Dieterich'chen Verlagsbuchhandlung, 1938).

9 Friedrich Schlegel (1772-1829) became notorious with his novel Lucinde (1799) whose heroine moves through adventures guided by her own conscience rather than by conventional morality. Friedrich and his elder brother August Wilhelm (1767-1845) and their wives were the core of what has been called the Berlin-Jena circle, which included, among others, Ludwig Tieck (1773-1853), who became an intimate friend of Novalis in 1799. Fichte was often present at the Schlegels' soirees. For biographical and bibliographical material on these and the other German romantic writers mentioned in the following pages, see the Romantik (Berlin: Kollekliv für Literaturgeschichte, 1966), which presents their lives and works in an encyclopedic format. Herbert and Elizabeth Frenzel's Daten deutscher Dichtung (Köln: Kiepenheur und Witsch, 1953) provides useful chronologies and brief sketches; for a fuller treatment see the Allgemeine deutsche Biographie.

${ }^{10}$ Hans Mayer, in Von Lessing bis Thomas Mann. Wandlungen der burgerlichen Literatur in Deutschland (Pfullingen: Neske, 1959), cannot reconcile the poet with the state official, and his difficulty has been shared by others.

${ }^{11}$ Schlegel and Tieck "sensationalized" Novalis by a creative editing which downplayed his practical side and made him assume the role of oracular prophet and visionary.

${ }^{12}$ Novalis Werke (Stuttgart: W. Hadecke, 1923). 
13 Donald P. Haase ("Romantic Facts and Civilized Myths: Novalis' Early Reception in France," The Comparatist 3 (1979), pp. 23-31) makes a solid case for an early acquaintance of the French with Novalis, and establishes a link between the Symbolists and German romanticism.

${ }^{14}$ Christenheit oder Europa treats the present as the antithesis of the "stable" Middle Ages; and hope is held out for a peaceful synthesis in the future. Many have seen in this evidence of the influence of Schiller, who had taught Novalis history at Jena in 1790. The immediate inspiration for Christenheit oder Europa was apparently the work of Friedrich Schleiermacher (1768-1834), whose Reden uber die Religion was published the year before Novalis wrote his essay. Novalis praises Schleiermacher by punning on his name.

${ }^{15}$ H. S. Reiss, The Political Thought of the German Romantics (Oxford: Basil Blackwell, 1955), p. 25. Pietism, however, was not the only element of the New Jerusalem. John Neubauer traces Novalis' pantheism, his identification of the poetic with the spiritual, as well as Schleiermacher's influence in Novalis (Boston: Twayne, 1980), pp. 77-99.

${ }^{16}$ Novalis was following Fichte in believing that the reform of absolutist and fragmented Germany was best served through education and change of each individual's perception rather than through political action of any kind.

17 "Young Germany" had 1ittle use for their predecessors: Heinrich Heine, for instance, called Novalis' poetry disease and his life "merely a dreamy pining away" (Sämtliche Schriften (Munich: Hanser, 1971), Vol. 3, p. 440). In the late nineteenth century Rudolf Haym would concur, considering it fortunate that romanticism had no influence in contemporary consciousness (Die romatische Schule (Berlin, 1870), p. 3). But in the late 1930's Willi Koch saw romanticism as a true expression of the deutsche Seele, which had never faltered (Briefe deutscher RomanIiker (Leipzig, 1937), pp. xvi-xviii).

18 John Neubaur has traced the changing image and enduring influence of Novalis in Novalis, pp. 155-166.

${ }^{19}$ On the Tieck - Freytag correspondence, see Edwin H. Zeydel, Ludwig Tieck, the German Romanticist (Princeton: Princeton University Press, 1935), p. 230 .

20 Two English biographies which relate Hugo's politics to his artistic development are Elliott M. Grant's The 
Career of Victor Hugo (Cambridge, Mass.: Harvard University Press, 1946) and the more recent volume by John Porter Houston, Victor Hugo (New York: Twayne, 1974).

21 These statements are a simplification for the purposes of argument. For French and German romanticism contrasted by a master in literary criticism, see Lillian R. Furst, Romanticism in Perspective (New York: Humanities Press, 1970).

22 Works on Chateaubriand's aesthetics and politics in English are scarce. The proceedings of the commemoration of the bicentenary of his birth were published as Chateaubriand Today (Madison, Wis.: University of Wisconsin Press, 1970); this contains essays in both English and French on various aspects of Chateaubriand's life and work.

${ }^{23} \mathrm{~N}$. H. Clement's work (see note 6 ) while valuable for detail, tends to praise French romanticism at the expense of the German variety, seeing the latter out of harmony with the "western heritage."

${ }^{24}$ Chaadaev's Letter and Kireevskii's On the Nature are to be found in Russian Intellectual History: An Anthology, edited by Marc Raef (New York: Harcourt, Brace \& World, 1966). On the Slavophile-Westerner controversy see Peter K. Christoff, The Third Heart (The Hague: Mouton, 1970); Thomas G. Masaryk, Zur russischen Geschichts-undReligionsphilosophie (Düsseldorf-Köln: Eugen Diederich, 1965); and Janko Lavrin, Russia, Slavdom, and the Western World (London: Bles, 1969).

25 Ludwig Tieck, the German Romanticist (Princeton: Princeton University Press, 1935), p. 168. Zeydel also discusses Tieck's debt to his close friend, Friedrich Schleiermacher, whose emotional enthusiasm for medieval painting, music, and sculpture was communicated to Tieck (pp. 94-100).

26 This was in a letter to Arnim shortly after the publication of Deutsche Mythologie in 1835. Quoted in Romantik, p. 337 .

27 From the brothers' foreword to the first edition of Deutsche Sagen. This work has been given its first English translation by Donald Ward as The German Legends of the Brothers Grimm, (2 vols. (Philadelphia: Institute for the Study of Human Issues, 1981)), who also furnishes excellent commentary on each legend and an extensive bibliographical index. The quote appears on p. 3 . 
28 The German Legends of the Brothers Grimm, p. 11.

29 Both brothers were among the "Göttingen Seven";

Jakob participated in the Frankfurt Parliament of 1848-49.

Ruth Michaelis-Jena has written a brief but adequate biography of the brothers which does not stress their scholarship at the expense of their politics or their selfimage as German patriots (The Brothers Grimm (London:

Routledge \& Kegan Paul, 1970)). 
CHAPTER IV

\section{JULES MICHELET AND THE "BARBARIAN INVASIONS"}

G. P. Gooch saw Michelet as "the greatest literary artist who has devoted himself to history in France." 1 Michelet's reputation as a romantic and nationalistic historian is well established: his literary style equals that of romantic fiction, and his portrayal of the growth of the French nation in The History of France is one of the classics of nationalist historiography. With this work Michelet did more than any other French historian of the nineteenth century to define "Frenchness" for the French.

In terms of national origins and national identity, no period was more important to French and German historians than that of the Germanic invasions of the late fourth and early fifth centuries. Did France owe anything except its name to the Germanic Franks? Nationalism demanded that French historians answer this question in the negative, while the same promptings called for an affirmative from German historians.

It will become apparent that Michelet's nationalism was not of the saber-rattling species. It was not xenophobic. Michelet did not deny the achievements of German culture, especially in art and philosophy. ${ }^{2}$ But he was 
nevertheless convinced that his own nation represented the apex of western civilization. ${ }^{3}$

Generally, in non-German scholarship the Germanic invasions are also known as the "barbarian invasions." German historians invariably use the term Völkerwanderung. Since Michelet was working within the "barbarian invasions" tradition, the connotations of this term and of Völkerwanderung ought to be examined.

"Barbarian invasions" immediately presents to the mind a picture of destruction, if not devastation. The implication is that the Germanic invasions of the Roman Empire were a catastrophe, that the movement of Germanic tribes into Gaul was always and everywhere accompanied by the violence of an organized military occupation. This may be regarded as the prevalent interpretation of the Germanic invasions of Gaul among French scholars in the 1830's, when Michelet began writing his History of France. A cataclysmic interpretation of the invasion of the Franks is the point of departure of Augustin Thierry's popular Narratives of the Merovingian Era. ${ }^{4}$

Thierry (1795-1856) injected his political liberalism (republicanism) into all of the history he wrote. His first publications were the Letters on French History (1820), urging the study and writing of national history in a manner that would tend to further republican sentiments. Thierry saw himself a champion of the "Gallic" Third Estate 
against the current representatives of the Frankish Invaders who had subjected the indigenous inhabitants of Gaul. The application of this master-slave interpretation to the history of England resulted in the History of the Norman Conquest (1826), in which a Norman domination of the "free" English is made the chief dynamic of English history through the fifteenth century. Thierry's Narratives (1840) are essentially romantic glosses on Gregory of Tours' seventh century History of the Franks whose focus is a supposed enduring Frankish subjection of the "freedom-loving" Gallo-Romans .

Thierry claimed a youthful reading of Les Martyrs as the source of his inspiration to study history. For him, liberal republicanism was a means for the amelioration of the historical exploitation of the "Gauls" (Third Estate) by the Frankish conquerers, who had established systems of exploitation far surpassing the Roman. It will be seen Michelet's interpretation of French history owed much to Thierry .

Völkerwanderung translates, roughly, as "migration of the peoples." There is here no implication of military force. Völkerwanderung connotes no violence, as in an armed invasion, the German word for "invasion" being Einmarsh. To repeat, Wanderung means a journey or migration. 
The connotations of these terms are indicative of French and German interpretations of the Germanic invasions in that they are mutually exclusive. While Francois Guizot (1787-1874) was a "Germanist" insofar as he credited the Germanic peoples with introducing the seeds of feudalism into Gaul, and was grateful to them for exposing the GalloRomans to "an energetic sense of personal liberty," he did not cease to view them as barbarians even though they seemed to have something of the noble savage about them:

There is something in the life of the American savages, in the relations and sentiments they bear with them in the midst of the woods, that recalls, up to $a_{5}$ certain point, the manners of the ancient Germans.

But Guizot had second thoughts, a few lines later, about his comparison of the ancient Germanic peoples to Thierry's Normans and James Fenimore Cooper's American Indians. "No doubt these pictures are somewhat idealized, somewhat poetic; the dark side of the barbaric manners and customs is not presented to us in all its grossness." 6 so while France did owe something to Franks, their movement into Gaul was not a Völkerwanderung but an invasion of crude and brutal barbarians.

Michelet rejected Guizot's contention that the ancient Germans contributed very much to the formation of the French nation:

Historians, whose authority has been great with me, have considered that we are indebted to the Germans for the spirit of independence and the 
genius of free personality. Before subscribing, however, to this opinion, it should be ascertained whether all races have not, in similar situations, presented similar characteristics.

For Michelet, there was nothing unique about what Guizot viewed as the personal liberty of the Germans of the fifth century. The anarchy common to all primitives prevailed among the tribal Germans. An apparent "freedom" is one of the characteristics of barbaric peoples throughout the world.

Though Michelet regarded the Germanic peoples as no different from other peoples in a primitive stage of development, he did detect one trait which seemed to make the Germans unique. This was not the "genius of free personality" Guizot had seen but rather its opposite. In his expression of his own reading of "Germanness" Michelet is in his best literary form:

These barbarians, who seemed instruments for universal destruction, become, whether wittingly or not, the docile instruments of the Church, who will employ their young arms in forging the steel which is to unite modern society. The German hammer of Charles Martel will ring upon, 8 and subdue, the rebellious spirit of the West.

What France owed to the Franks was the power of the medieval Church, which Michelet regarded as an unfortunate development in the history of the nation. ${ }^{9}$ The German contribution was negative. Michelet's reference to "the rebellious spirit of the West" is a clue to his definition of "Frenchness." He believed it is to the Celtic peoples 
that one must look for the free personality, and he was sure that the French character owes more to the Celtic than to the Roman or German "genius."

The mixed Celts, who are called French, may be partially illustrated by the pure Celts, Bretons, and Welsh, Scotch and Irish. Let me be permitted to pause, and to raise a stone at the cross-way where these kindred races are about to separate by such opposite roads, to follow so different a destiny; for I should be pained did I not take a solemn farewell of those people, from whom the Germanic invasion will isolate our France. ${ }^{10}$

The invasions had the effect of scattering the Celts and dividing them into various branches. The Bretons are the only "pure" Celts still existing in France; the French are "mixed Celts."

Michelet viewed France as participating in a sort of ethnic brotherhood with the Irish and Scotch, from whom the French are separated by the Germanic English. The conviction of the Celtic origins of "Frenchness" was to become more pronounced in Michelet's later work. In The People (1846) he will state that "In France the Celtic element has combined with the Roman, and the two are one. The Germanic element, which some people are always talking about, is really imperceptible." 11

"Frenchness" derives from the original Celtic inhabitants of Gaul. It is characterized above all by an independent outlook. It is sensual, often impractical. "Frenchness" equals the free personality desiring equality, which Guizot and others had attributed to the Germans. 
But "Germanness" is in fact just the opposite of "Frenchness": it is docile, plodding but thorough, and tends to view beauty as an extravagance. "Germanness" equals the personality desiring hierarchy and order.

Michelet's interpretation of the Germanic invasions as a catastrophe accords with Thierry's insofar as they dispersed the Celtic peoples and made them the "underdogs" of Europe. The only unique trait of the tribal Germans was their docility, since in all else they resembled other primitive peoples. As a Frenchman Michelet had no trouble avoiding an idealization of the early Germans, but as a romantic he could not resist an idealization of the Celts. 12

This version of the "barbarian invasions" theme is the essential basis of the picture which seems to have formed in Michelet's mind as he studied the primary sources of the disintegration of Roman Gaul. These classical materials are identical to those used by Gustav Freytag some thirty years later. Relevant passages from Julius Caesar, Strabo, Ammianus Marcellinus, Suetonius, and Sidonius Apollinaris are the point of departure for both Michelet and Freytag, though Freytag, writing for a wider public, dispensed with all but an occasional footnote. Working over the same materials the Frenchman and the German produced quite dissimilar narratives. That their readings of an identical text could be worlds apart 
is illustrated most obviously in the case of Cornelius Tacitus .

The Germania of Tacitus is an indispensable source for the manners and customs of the Germanic tribes, the more so since it is the only "eye-witness" source treating at any length of these peoples before the invasions. ${ }^{13}$ Written circa 98 A.D., the Germania describes aspects of Germanic life three centuries before the invasions began in earnest. For this reason, the Germans of Tacitus cannot be identical to the Franks who began to occupy northwestern Gaul in the fifth century. But there are other problems with Tacitus as a source. As F. L. Borchardt observes, "Tacitus had his information from first or second hand, and conveyed it through his urbane writings to an equally urbane Roman audience." 14

Tacitus was not only providing his Roman audience with a description of the "quaintness" of the Germanic peoples, he was suggesting that the Germans, though savage, were in some respects (particularly in personal courage and marital fidelity) superior to their more sophisticated Roman contemporaries. When interpreted in the context of its intention, then, Germania must be seen as an example of very special pleading, but not on the behalf of the Germanic peoples. Tacitus makes the Germans noble savages whose example should shame his Roman audience. 
For obvious reasons, many German historians have preferred to take the noble savages of Tacitus at face value. This was a preference dating back at least to Konrad Celtis, who produced the first German translation of Germania in 1500. So much have the ancient Germans of Tacitus become a part of a German identity that selections from the Germania are still required reading for elementary school children in most of West Germany today. Gustav Freytag, as will be indicated in the next chapter, was solidly within this ongoing German tradition.

French reaction to Germania was varied. Michelet expressed his evaluation of it in these words:

Notwithstanding the lively colors with which

Tacitus delighted to paint them, the manners of the early inhabitants of Germany do not appeared to have differed from those of most barbarous nations. 15

The moralizing Roman senator is regarded with a skeptical eye. Michelet was selective in his acceptance of Tacitus, making use of his simpler observations and passing over the high-flown praise of the virtues of the ancient Germans as having no real bearing on the manners and customs of the people they purport to describe. In short, Michelet never lost sight of the axe that Tacitus was grinding in Germania.

In the excerpts from History of France cited above, the word "race" is made to assume uncommonly weighty connotations. For Michelet the Bretons and Welsh are not, as it 
would usually be put today, "related ethnic groups," but "kindred races." And they are both, he says, "pure Celts." Nevertheless, Michelet stresses their distinctness as well as their common identity.

It is impossible to scan even very brief sections of the History of France without being forced to come to terms with the identification of each of the numerous European ethnic groups as a specific "race"; the word appears with this significance on nearly every page of the text. But, despite first impressions, the frequency of its appearance does not indicate casual or careless use.

The problem of race had preoccupied the French for centuries, partly because arguments based on race were used to back political opinions. ${ }^{16}$ In the seventeenth and eighteenth centuries the aristocrats Francois Hotman, Etienne Pasquier, and Henri de Boulainvilliers used Tacitus to protest the "Roman" absolutism of the French kings. Political freedoms (by which they meant privileges of the nobility) were held by their "Germanic thesis" to be of Frankish origin, dating from their seizure of Gaul.

Race remained entangled with politics after the Revolution, but their was an abrupt change of alliance. It has been noted that republican liberals like Augustin Thierry made the Germanic Franks take the place of the Romans as the historical enemies of political liberty. It was the "Celts" who were now cast as the freedom-loving 
"race," though just who or what these people were was never established. ${ }^{17}$ Their outlines were so elusive that the Celts served well as carriers of whatever features one might wish to give them; Michelet followed Thierry in giving them a "free spirit."

Arthur de Gobineau (1816-1882) unquestionably did more than any other writer to promote the "Nordic myth" version of racism, yet his Essay on the Inequality of Races (1855) is in an important sense only an articulate distillation of the general habit of race-thinking in the nineteenth century. ${ }^{18}$ Darwin's work, which was soon twisted into "Social Darwinism," contributed to the race mania, as did the nationalistic competition between nationstates. $^{19}$ Race-thinking was a central concern of the widespread curiosity about national origins and of the historians, including Michelet, who investigated them. Race was a legitimate concern of his generation. ${ }^{20}$ One cannot condemn Michelet on these grounds unless one is prepared to reject a good deal of the thought of his century. Such arrogant judgement ought to be avoided, since race-thinking is very much alive today. John $R$. Baker insists on the physiological and genetic reality of race and divides human beings into six "major races" containing twenty-six "subraces."21

Michelet was aware that what was understood by the word "race" in his day was nearly identical to the original 
meaning of the word "nation," and he had gained this awareness through his studies of an eighteenth century humanist. Michelet began the translation of Giambattista Vico's Scienza Nuova when he was in his late twenties and still uncertain of his vocation. The enthusiastic reception of this work when it was published in 1827 was one of the factors securing his appointment to a chair of philosophy and history at the Parisian École Normale. ${ }^{22}$ The relationship between Michelet and Vico was to persist throughout Michelet's career.

Vico (1668-1744) was a Neapolitan classical scholar who was one of the first defenders of humanist philosophy against the criticisms made of it by the devotees of Cartesian thought. 23 Vico spent most of his mature years in composing a "new science" intended to demonstrate that a humanist philosophy which drew upon the study of history and literature was in fact a science superior, in its capacity to explain reality, to those fashionable systems of explanation based on the exact sciences of physics and mathematics. Vico wanted to wipe from Descartes' face the contemptuous smirk with which he regarded traditional philosophy and history. 24

Vico approached history with the conceptual suppositions provided him by an intensive philological training. That is to say, history was for Vico one type of literature; he made no distinction between the "cold, hard facts" as 
entities imperfectly reflected in literary accounts of them and those literary accounts themselves. He approached all texts, whether "fact" or "fiction," as literature. This permitted Vico an extensive freedom of analysis; he could deal with mythological material as a type of historical source and could likewise attempt to "read between the lines" of the classical historians and of the legal materials of classical Greece and Rome.

Vico studied history in the process of studying literature in the very broad sense just outlined. He was convinced that literature provides a type of journal kept by a culture, in which it can be seen to pass through stages of development that parallel those in the life of each individual. Vico called these successive stages the "Age of Gods" (infancy), the "Age of Heroes" (youth), and the "Age of Men" (maturity).

To be sure, Vico did not venture to suggest that "pure" literature alone was sufficient for the task of understanding the past. But he was adamant that the past could not be retrieved to the fullest extent possible by any method of study which neglected the creative literature of the past. No accumulation of data, regardless of its extent, could equal the "retrieval" potential of a work of creative literature, because in reading creative literature one re-created the milieu of its composer. In these 
terms Vico gave a more precise formulation of Einfühlung (empathy) than Herder ever did. 25

A digression will illustrate what Vico meant by his insistence on the re-creative powers of pure literature. When a sensitive and attentive reader takes up the Iliad, he may undergo a certain re-experiencing of a specific past. It is too much to say that the reader will re-experience an actual seige of Troy by Greeks, but the manner in which the poet chose to present that actual seige is re-experienced. It is not the heroes who are "resurrected" in this process, but the poet and his audience. In just the same way, though the characters of Dickens may be said to "live" with more vividness than those of many other writers of English literature, it is actually only Dickens himself who "lives" in the novels. The French Revolution looming in the background of A Tale of Two Cities might or might not be of interest to a student of the French Revolution, but it constitutes a primary source for anyone investigating the various English reactions to the Revolution.

All of this is commonplace today. One of the results of a widespread awareness of the intimate connection between literature and history has been its deliberate exploitation in the form of the popular "historical novel." Vico's achievement was many-faced, but not least of his accomplishments was an exploration of the interrelations of 
literature and history, and an explicit statement that a change in literary style indicates change in the culture it expresses.

It was still necessary for Vico to establish the superiority of history as an adjunct to philosophy. He had linked history to classical literature, but he wished to elevate history, as a means of explanation in its own right, to the level of mathematics or physics. He accomplished this by the use of an epistemological distinction first elaborated in medieval scholasticism, which adumbrated the problems Kant was to face in the form of the notorious Ding an sich.

This must be briefly stated. As an orthodox Catholic, Vico accepted that perfect knowledge was denied to all but God. God has knowledge of everything because it is His creation. Vico proceeds to make creation (or re-creation) the sole criterion of knowledge. We cannot know natural phenomena in as complete a sense as we are capable of knowing human phenomena, which we create ourselves. The "how" of nature may, in a superficial sense, be observed and understood--men like Newton may make clever deductions from such observations--but this kind of knowledge is merely of reflections and shadows, since the "what" of external nature is known only to God.

Men can achieve a complete knowledge only of what he himself creates, because only in human phenomena is he both 
participant and observer. History, being the record of men's past creations, furnishes therefore a knowledge potentially much more comprehensive than that possible through the pursuit of mathematics or the natural sciences. Vico is telling Descartes' followers that they are deluding themselves because they are disregarding the limits of human knowledge. This is just what the Inquisition told Galileo.

As a philologist Vico maintained that to know the origins of anything was to know what was most important about it. In the Vichian view, then, true philosophy must be based on historical study, since only history can provide the data on the origins of human institutions. Modern men can "know themselves" through retrospective visits to the earlier "Age of Gods" and "Age of Heroes" experienced by Greece and Rome and re-experienced by the peoples of Europe after Rome's collapse. This revisiting can be achieved by the study of history and literature. Vico's philological background was also responsible for his fastidious use of terms. He construes "nation" in its original sense as a "people," "race," or the modern expression "ethnic group." A shared culture or common language is the crucial criterion in Vico's reading of "nation," as it is in Herder's Volk. Ethnic identities do often, but do not necessarily, coincide in the Vichian concept of "nation." Entirely absent are the combative, 
political connotations attaching to the word in the polemics of the later eighteenth century, when the "nation," representing "the people," was defined in opposition to the "tyranny" of an absolutist regime. Michelet made use of both the original and modern meanings of "nation" in the History of France, but he is apt to use "race" where Vico would have used "nation"; in his very popular section on the regions of France Michelet argues that the various distinct "races" of the French are in part a result of the distinct geographical regions and climates of France. Theodore Zeldin has recently restated a problem that was very familiar to Michelet, and with which every historian of France has had to cope. This problem is that the national identity in France has been no less problematic than elsewhere. 26

The Vichian concept of the life-cycle of nations provided Michelet with a base for his treatment of the early Middle Ages in the first volumes of the History of France. In a very real sense these first volumes may be regarded as early medieval France according to Vico. Michelet portrays the early Middle Ages as an "Age of the Gods," in which the Church succeeded in intimidating Gaul's superstitious indigenous inhabitants as well as its recent invaders from the East, and imposed its ecclesiastical hierarchy as a principle of order based on its power as keeper of the mysteries. The later volumes seem to place 
Charles Martel and Louis XIV, respectively, at the beginning and the end of an "Age of Heroes." Even when his narrative skills are deployed to depict modern French history, and the Vichian "nation" is thoroughly blended with its later political connotations, Michelet makes the revolutionary era France's transition to the "Age of Men" according to Vico.

But while Michelet's debt to Vico has been often remarked (in part because he himself called attention to it), he followed his master just so far and no further. Michelet's borrowing from Vico was in fact very selective.

The conceptual distance between early eighteenth century Naples and post-revolutionary Paris was considerable, and would not allow Michelet to accept Vico's complacent referral of the final end or goal of history to the mercies of an unknowable Providence. Denying Vico's corsi e recorsi metaphor of a cyclical or spiral movement in human history, Michelet accepted Vichian "poetic wisdom," through which men created the basic institutions of social and political life in a process similar to that to be observed in the creation of myth and legend. 27 Denying that the rationalist "dry-as-dust" approach of the philosophès was capable of accurately depicting historical processes, he nevertheless espoused their conviction that history follows, with detours, a rational course toward some recognizable destination. It will be seen that 
Michelet also inherited an Enlightenment tendency to conceive history as a struggle between two opposed or contradictory forces.

Michelet never left his public in doubt as to his preconceptions or as to "where the story was going" in his manner of its telling. In 1831, two years before the first volumes of History of France appeared, and still elated with hopes for the results of the recent revolution, he told his students at the École Normale,

With the world began a war which will only finish with the end of the world, that of man against nature, mind against matter, freedom against fatality. History is nothing else 28 than the record of this ceaseless struggle.

The perpetual struggle of "freedom against fatality," which he was soon to narrate in the History of France, and in which it seemed that freedom had won the latest bout, was to be the central organizing principle Michelet consistently applied to the past. But the Revolution of 1830 was in Michelet's mind merely one of those stiff skirmishes that often take place after the major and decisive battle. This decisive battle was, of course, the Great Revolution of 1789. At that time freedom had been articulated with such eloquence and defended with such tenacity that the forces inimical to freedom could never again achieve a lasting advantage. So Michelet hoped.

In the mid-1840's Michelet interrupted work on his History of France to begin another narrative, his History 
of the French Revolution, the first volumes of which appeared in 1847. The History of France was not resumed until 1853, when the French Revolution narrative had been completed. In his introduction to the English edition of French Revolution, Gordon Wright explains this "leap" in narration in terms of Michelet's impatience to treat what he regarded as the greatest moment in all of history. 29 Gooch explains the leap differently: "As Theirs and Mignet had used the French Revolution to overturn Charles X, so Michelet and Lamartine employed it to undermine his successor."30 Both Wright and Gooch are correct. The liberal enthusiasm for the July Monarchy in which Michelet shared gradually dampened during the following decade and was finally extinguished after Guizot's ascendency. Michelet was one of the chief targets of Louis Veuillot's campaign to eliminate "seditious ideas" from the universities (Michelet had taken Guizot's place at the Sorbonne in 1834). But Gooch need not have made such an issue of the political implications of French Revolution, since Michelet stated them, as explicitly as censorship allowed, in his preface to the work. In dwelling on the ideals of 1789 , Michelet intended to make apparent the betrayal or perversion of those ideals by the Guizot ministry. And this was not the mere rhetoric to which Michelet was so prone. Though he outlasted Guizot and Veuillot, his outspoken 
republicanism was to cost him the Chair of History at the Sorbonne under Louis-Napoleon.

But Michelet's "leap" also makes sense without any reference to contemporary politics; it can be regarded as a logical consequence of his reliance on Vico for a model of history in its broadest sweep. Because, in Vichian terms, the Revolution can assume the character of the decisive event marking the entry of the French nation into the "Age of Men." The nation, construed as "the people," reaches its maturity in 1789, and sets about consciously creating the institutions intended to preserve the freedom of "the people."

In addition to this much of Vico brought to bear on the Revolution, Michelet injects much emotional color, and not only his own, since the Revolution had not yet quite disappeared from living memory. Rumors which circulated in revolutionary Paris and recollections of witnesses, selected not for their accuracy but for their vividness, make the French Revolution a pioneer work in the recording of oral history.

The flaws of the French Revolution narrative are sufficiently glaring to have been remarked many times, but its failure as history is inversely related to its validity as a mirror of Michelet's conception of the movement and the culmination of the historical process. He presented the Revolution as a grand Manichaean contest in which Good 
("the people," or "the nation" so construed) was victorious over Evil (the ancien regime). The emotional optimism given expression in The People, published just the year before the first volumes of French Revolution, are the foundation of Michelet's view of 1789 .

From this perspective, it becomes clear that Michelet was willing to drop History of France because it was, compared to the Revolution, of secondary importance. But there was more than that. For Michelet, everything that happened in France before 1789 had meaning only in terms of furthering or opposing the "freedom" finally achieved in that year. The Middle Ages were for Michelet in the nature of an extended prologue and preparation for the year 1789. This is why his chief concern with the "barbarian invasions" is in the opportunities they afford him in locating the freedom-versus-fatality dialectic at the beginning of the medieval period. In the early volumes of History of France the "Celtic race" is defined as the freedom principle; the "German race" as the fatality principle.

These principles themselves are what Michelet wishes to depict, not the details of their conflict in those past events known as the "barbarian invasions."

Vico's influence was given extended attention here because it was dominant in Michelet's formulation of a 
philosophy of history, but other influences bearing on Michelet's career ought now to be briefly mentioned.

Francois Guizot was ten years Michelet's senior, a historian-turned-politician whose history and politics are the antithesis of Michelet's and whose career is nevertheless very closely interwoven with the younger man's. 31 Michelet had studied under Guizot, who was favorably enough impressed with him to help Michelet secure his first academic appointment in 1827 at the Parisian Ecole Normale. Michelet also had Guizot to thank for his continued position at the Sorbonne some years later, during the period of Veuillot's attacks.

Guizot is today much better known for his career in the chaotic politics of France, from which the results of the year 1848 finally excluded him. But his manner of writing history is possibly as responsible for this as is his prominence in the ministry of Louis-Phillipe. The lectures given in the $1820^{\prime} \mathrm{s}$ which form his History of Civilization in France view the past in terms of institutions described in a style which purges them of virtually all human content. But Guizot's political "clout" was of more use to Michelet than his approach to history and his style of writing it.

Guizot was instrumental in re-establishing state support for historical research, which had suffered during Napoleon's supremacy. In 1833, the same year that he 
launched a nationwide program to reduce illiteracy, Guizot helped to establish the Société de l'histoire de France, which funded systematic research in the national archives. The Documents Inedits produced by this organization parallels the German Monumenta. Guizot also broadened state support of the College de France, of which Michelet became a member in 1838 .

Above all, it was Guizot who from 1831 placed the national archives at Michelet's disposal and made possible his History of France. Guizot's protecting political influence maintained Michelet in his privileged position regardless of the latter's republican sympathies. Evidently the two men agreed to disagree about politics while respecting one another as scholars. In any case, within five years of Guizot's fall in 1848 Michelet had lost his Chair of History at the Sorbonne, his place in the College de France, and his carte blanche at the national archives.

It was remarked above that although Michelet rejected the Enlightenment's rationalistic treatment of history he accepted its view of history as a conflict of opposing forces. For the philosophès these forces tended to be "reason" and "unreason"; for Michelet they were "freedom" and "fatality." This observation ought to be broadened. Lionel Gossmann has seriously questioned the validity of a time-honored generalization concerning the philosophè's views of the Middle Ages. ${ }^{32}$ Gossmann has identified 
several eighteenth century French scholars, of whom La Curne de Sainte-Palaye was the most influential, as medievalists as well as friends of the Enlightenment. Voltaire notwithstanding, medievalists were not universally scorned by the philosophès.

Gossmann's research has an impact today which it would not have had for Michelet. Aware of Sainte-Palaye's philological work, Michelet might have been struck with the similarities it bears to Vico's but he would not have been surprised than an eighteenth century intellectual could be "enlightened" and also be a medievalist. Many of the textbook generalizations which determine the "Enlightenment" for us today are the creation of the last century; for Michelet, the Enlightenment was one of the enterprises of his father's generation. Distance facilitates simplification, but Michelet was much too close to the Enlightenment to reduce it to a monolith of pure rationalism and nothing else.

Michelet would have thought as little of the late sixteenth century "Germanist thesis" of Francois Hotman and Etienne Pasquier as he did of Guizot's recasting of it. He regarded these early spokesmen of the "noble Franks" as apologists for the hereditary nobility, which in fact they were. He likewise dismissed Sainte-Palaye's eighteenth century version as special pleading on behalf of the noblesse de robe. ${ }^{33}$ None of these historians had spoken 
for "the people" as he did. They had used the "Germanist thesis" in the interests of their class (Hotman, Pasquier, and Sainte-Palaye) or of their politics (Guizot).

In the interests of "the people" whose story he was telling, Michelet rejected any reading of that story which seemed, in the initial chapters, to place those people (the "Celtic races") elsewhere than in the foreground.

Much has been made of Germaine de Staël's De 1' Allemagne (1810) as a determinant of nineteenth century French stereotypes of Germany as a wooded land of thatched cottages and of the Germans as "noble savages," simple but poetic, dreamers rather than practical citizens. ${ }^{34}$ Any close reading of De l'Allemagne, however, will demonstrate that she did not present German life as an idyll unalloyed with baser elements. If de Staël is over-generous in attributing "high sentiment" to the average German, she is also critical of the inability of these sentiments to mitigate his crude and even brutal behavior. De l'Allemagne, in fact, attempts a balanced appraisal of Germany in that de Staël finds as much to condemn as she finds to praise in the life and thought of the Germans. The suppression of this work by Bonaparte's censors owed more to its author's previous reputation than to any pro-German tendency in the work itself. 35 For these reasons, the characterization of de Staël as a Germanophile 
must be seen as a simplification that will not hold up under close examination. 36

The "Germanness" described by de Staël was projected by Michelet onto the Germanic tribes of the fifth and sixth centuries as the essential "spirit" or identity of a "German race" which was as immutable as that of the French "race of mixed Celts."

Given his literary powers, Michelet would have portrayed his Germans and Celts as he did with or without Madame de Staël's De l'Allemagne. But his familiarity with her work no doubt made his portrayal of the Germans somewhat easier, perhaps so much easier that felt justified in not citing her contribution.

Michelet omitted mention of his debt to Germaine de Staël, and he was outspoken in denying that romantic literature had influenced his narratives. But he cites Chateaubriand's Les Martyrs in the History of France. ${ }^{37} \mathrm{He}$ also cites, with praise, the works of the Thierry brothers, Augustin and Amédée, who in turn cited Chateaubriand and Scott as two of the chief inspirations of their historical narratives. The only conclusion to be drawn from this is that Michelet was certainly influenced by romantic literature to a degree that he felt it necessary to deny that influence. In spite of his denial, his literary style comes from no other source. ${ }^{38}$ 
Michelet came by his republicanism honestly. 39 His father was a printer, a champion of the ideals of 1789 , whose small business had been ruined by the same Napoleonic censorship that gave Madame de Staël so much trouble. Rather than attempting to conceal his lowly origins, Michelet made them a point of pride, feeling that they, much more than his academic honors, qualified him as a spokesman of "the people." He chose this role early and maintained it to the end of his life, continuing to aid the cause of republicanism in all forms after his expulsion from academia under Louis-Napoleon. He was one of the Second Empire's most venomous critics.

What happened to Michelet in his later years is not unlike what befell the American historian Charles Beard, who also ended his career in fulminations against a leader who he believed had "betrayed" the people. Both Franklin Roosevelt and Louis-Napoleon had promised peace just before the onset of war, and neither Beard or Michelet could forget it.

Michelet viewed the Second Empire as representing a movement further away from the ideals of 1789. His sense of bitterness and frustration deepened throughout the $1850^{\prime} \mathrm{s}$ and $1860^{\prime} \mathrm{s}$, and was climaxed by the disaster of the Franco-Prussian War. France Before Europe was written in December of 1870 and January of 1871, and so it documents Michelet's reactions to events in an immediate way. $\mathrm{He}$ 
hoped, like many Frenchmen, that the seige of Paris would somehow be broken by the disorganized provincial forces under the nominal command of Gambetta. When this deliverance failed to materialize and the French surrender became official, Michelet could still write,

Some think--friends and enemies--that we are weakened by dissension or social problems, that we are verging on civil war. That is a mistake--our 40 very excitement makes us not weak but formidable.

But it was Michelet, of course, who was mistaken. The Commune and the blood-bath that ended it seem to have set the capstone on twenty years of disillusionment for Michelet. His last work, on nineteenth century French history, is marred by his bitterness and tends to degenerate into philippics against the "traitors" to the ideals of 1789. He died in 1874 .

\section{CONCLUSION}

Michelet's narratives were consistent with a philosophy of history adopted from Vico, as has been discussed above. This means that Michelet treated the "barbarian invasions" in such a way that he elicited whatever that complex of events contributed or failed to contribute to the process of the consolidation of the various French "races" into "the French people" which finally recognized itself as such in 1789 . 
In terms of this process of national consolidation, the invasions were positive in that they provided the popes with a means (the peculiarly German docility) to curb the independence of the Celts and of the Celtic Church, since the Celtic "spirit of rebellion" was in this case an impediment to the consolidations of the "races." The negative aspect of the invasions was the temporary imposition of a foreign domination on the Celtic homeland. The foreigners were soon assimilated.

But neither the positive or negative consequences of the "barbarian invasions" could have decisively altered the inexorable movement toward national consolidation which was Michelet's version of Providence. In Michelet's conception of the history of France, the "barbarian invasions" figured as an episode, and not as a major event. They were too far removed from 1789 to be any more than that. Gustav Freytag, however, felt that the Germanic invasions were an event of the highest importance, for reasons which are examined in the next chapter. 
NOTES: CHAPTER IV

${ }^{1}$ G. P. Gooch, History and Historians in the Nineteenth Century (New York: Longmans, Green \& Co., 1920), p. 175. This pithy judgement of Michelet has not been overturned in the years since Gooch gave it.

2 Jean Seznec maintains that Michelet's rise from a petite bourgeois background to academic eminence left him with a confused self-image. She cites his Journal as evidence that the wood sculpture of the fifteenth century master Tilman Riemenschneider depicting the common man, which greatly impressed Michelet, encouraged his identification with "the people." ("Michelet in Germany," History and Theory, 16, No. 1 (1977), 1-10.

${ }^{3}$ This is at its most visible in his precis d'histoire moderne (Survey of Modern History), published in 1827, but it is a constant assumption with Michelet. That the Slavic peoples, especially, suffer in comparison with the French was one message of Michelet's piece on The Legend of Kosciuszko (1851), a message to which Alexander Herzen was quick to reply. Herzen politely but firmly upbraided Michelet for his French ethnocentrism. This letter is included in Basil Dmytryshyn's Imperial Russia: A Source Book, 1700-1917 (New York: Holt, Rinehart \& Winston, 1967). On Russian romantic nationalism see the work of Edward C. Thaden, Conservative Nationalism in Nineteenth Century Russia (Seattle: University of Washington Press, 1964), and "The Beginnings of Romantic Nationalism in Russia," American Slavic and East European Review, 13 (1954), 500-521.

${ }^{4}$ A. Thierry, Narratives of the Merovingian Era (London: Wittaker \& Co., 1845).

$5_{F}$. Guizot, History of Civilization in Europe (New York: A. L. Burt, 1880), p. 47.

${ }^{6}$ Ibid., p. 48 .

${ }^{7}$ History of France (New York: D. Appleton \& Co., $1882)$, p. 77 .

$$
{ }^{8} \text { Ibid., p. } 67 .
$$


9 The cautiously shrewd diplomacy of many Gallo-Roman bishops (especially Gregory of Tours) in using the internecine quarrels of Clovis' descendants to strengthen the position of the Church was what Michelet had in mind. Once secure in the Merovingian kingdoms, the Church began to persecute the native folklore beliefs it could not assimilate. This is the thesis of La Sociére (1862), a classic romantic study of "sorcery" as an expression of popular despair. It is a forerunner of contemporary studies viewing the witch as a victim of male-dominated culture and of Christian misogyny.

${ }^{10}$ Ibid., p. 70 .

11 The People, translated by John P. McKay (Urbana: University of IIlinois Press, 1973), p. 193.

12 "Celticism" was established well before Michelet wrote. It moved gradually into academe from origins in the Ossianic cult and romantic medievalism. Nineteenth century Celticism will be discussed further below.

${ }^{13}$ Julius Caesar, of course, was also an "eye-witness" of the Germanic peoples, but they appear in his Commentaries only as cunning and deceitful adversaries. Their manners and customs are scarcely mentioned by Caesar, who adds nothing to the fuller treatment given by Tacitus.

14 German Antiquity in Renaissance Myth (Baltimore: Johns Hopkins Press, 1971), p. 303.

15 History of France, p. 75.

${ }^{16}$ See Jacques Barzun (The French Race: Theories of its Origins and their Social and Political Implications (New York: Columbia University Press, 1932)), who regards Tacitus as the source of the "Nordic myth" explored more fully in its nineteenth manifestations in Race: a Study in Superstition (New York: Harper \& Row, 1937).

17 Barzun's Race, pp. 108-114.

${ }^{18} \mathrm{~A}$ thorough study, in a biographical format, is given by Michael D. Biddiss, The Father of Racist Ideology: The Social and Political Thought of Gobineau (London: Weidenfeld \& Nicholson, 1970). Gobineau's essay has been translated by Adrian Collins (New York: Putnam's Sons, 1915). 
19 Michael Banton's The Race Concept (New York:

Praeger, 1975) provides a less specialized and less judgmental view of the subject than Barzun, with more attention to the evolution of ideas.

20 Michelet's American contemporary Robert Knox's treatment of the Celts would have pleased him, as his chapter on the Germans would have pleased Freytag (The Races of Men (Philadelphia: Lea \& Blanchard, 1850). Appendix.

${ }^{21}$ Race (New York: Oxford University Press, 1974),

22 On the translation of vico into other languages, see Max Harold Fisch's introduction to The Autobiography of Giambattista Vico (Ithaca: Cornell University Press, 1944), pp. 75-76.

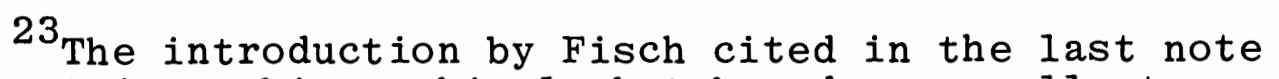
also contains a biographical sketch and an excellent section on Vico's influence and reputation through two centuries (pp. 61-107). Benedetto Croce's The Philosophy of Vico (translated by R. G. Collingwood (New York: Russell \& Russe11, 1964)) telis the reader as much about Croce's philosophy as about Vico's. Indispensable for an intensive study of Vico is the volume edited by Giorgio Tagliacozzo, Giambattista Vico: An International Symposium (Baltimore: Johns Hopkins Press, 1969), which presents articles by a score of scholars. The paper by Alain Pons, "Vico and French Thought" (pp. 165-185) is particularly relevant for the connection between Michelet and Vico. J. G. Robertson (Studies in the Genesis of the Romantic Theory in the Eighteenth Century (New York: Russell \& Russel1, 1962)) discusses parallels between the New Science and romanticism.

${ }^{24}$ The rough précis of Vico's philosophy which follows is drawn primarily from the introduction by the English translators of Vico, Thomas Goddard Bergin and Max Harold Fisch, to The New Science of Giambattista Vico (Ithaca: Cornell University Press, 1948), pp. xxi-liii.

25 Which was perhaps one of the reasons why Herder was content to leave Vico in the relative obscurity from which Michelet rescued him. See Isaiah Berlin, Vico and Herder (London: Hogarth, 1976).

26 France 1848-1945 (Oxford: Clarendon Press, 1977),

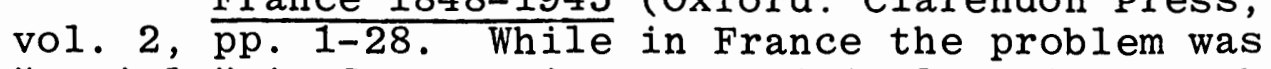
"racial," in Germany it was political, owing to the multiplicity of the German states. 
27 Vico called this creative process "poetic wisdom" because the Greek for "creator" was "poet."

${ }^{28}$ Quoted in G. P. Gooch, p. 177.

29 History of the French Revolution (Chicago and London: University of Chicago Press, 1967).

${ }^{30}$ G. P. Gooch, p. 181.

${ }^{31}$ A biographical sketch of Guizot with special attention to his relationship in scholarship and politics to Michelet is given in Stanley Mellon's editor's introduction to Historical Essays and Lectures of Francois Guizot (Chicago: University of Chicago Press, 1972).

32 Medievalism and the Ideologies of the Enlightenment (Baltimore: Johns Hopkins Press, 1968).

${ }^{33}$ Gossmann agrees, pp. 276-78.

${ }^{34}$ Madame de Staël has attracted a host of biographers. Providing its context is kept in mind, A. Sorel's work is of value (Madame de Staël, translated by Fanny Hale Gardiner (Chicago: McClurg \& Company, 1891)). J. Christopher's Mistress to an Age: A Life of Madame de Staël (New York: Bobbs-Merrill Company, 1958)) has not yet been surpassed by its feminist critics. Peter Gay offers a biographical introduction to de Staël's own Ten Years of Exile (translated by Doris Biek (New York: The Saturday Review Press, 1972). Among the best of recent work on de Staël is that of Madelyn Gutwirth (Madame de Staël,

Novelist (Urbana: University of Chicago Press, 1978), who views de Staël primarily as a literary artist and only secondarily as a publicist.

35 Morroe Berger's introduction to Madame de Staël On Politics, Literature, and National Character (Garden City: Doubleday, 1964), pp. 81-89.

${ }^{36}$ Peter Gay points out that she was also popularizing the Schlegel's distinctions between a classical and a romantic aesthetic. Ten Years of Exile, pp. xxvii-xxviii.

37 Being a Breton, Chateaubriand would have been regarded by Michelet as a "pure Celt," and therefore an especially qualified authority on matters genuinely French.

${ }^{38}$ In the late $1820^{\prime} \mathrm{s}$ Michelet was drawn to the German collections of folklore and fascinated by romantic fiction, particularly that of Ludwig Tieck, whom he read avidly. He 
also read Görres' Volksbücher, Bretano and Arnim's Des Knaben Wunderhorns, as well as the work of the Grimm brothers. For a time, Michelet was planning to pursue similar studies in the folklore of France. See Charles Rearick, "Symbol, Legend, and History: Michelet as Folklorist-Historian" in French Historical Studies, 3, No. 1 (1977), 72-92.

39 John P. McKay gives special emphasis to the formative aspects of Michelet's early life in the introduction to his translation of The People (Urbana: University of Illinois Press, 1973).

${ }^{40}$ France Before Europe (Boston: Roberts \& Brothers, 1871 , p. 109). 
CHAPTER V

GUSTAV FREYTAG AND THE VÖLKERWANDERUNG

Gustav Freytag's historical narrative Bilder aus der deutschen Vergangenheit $(1859-1862)$ and the novel Die Ahnen (1872-1880) presents the Germanic invasions as a Völkerwanderung. The portrayal of the Germanic movement given by Freytag in these two works was immensely popular with his countrymen toward the close of the nineteenth century. Writing before the First World War, G. P. Gooch had no doubt that "Together (Bilder and Die Ahnen) have done more to interest German men and women all over the world in their own history than the writings of any other man."1 The appeal of Freytag's work cannot be dissociated from the nationalism which aided the emergence of Germany as a nation-state in 1871 and which assumed such exaggerated proportions in the years following unification. Freytag's writings helped to provide the militant pride of his countrymen an historical content which also served as a tacit justification of that pride. For this reason, a study of Freytag's work can provide the student with a clear conception of what it was that patriotic Germans of the late nineteenth century chose to believe about their history. 
Freytag was born in 1815 at Kreuzburg, Upper Silesia. ${ }^{2}$ His father held a minor post in the Prussian bureaucracy, which made it possible for him to begin studies at Breslau. Freytag early demonstrated an aptitude for language and a fascination with German antiquity. After completing his course in Breslau, Freytag continued his studies in German language, literature, philosophy and history under Karl Lachmann at the University of Berlin. Receiving his Doktor-Diplom in 1838, he obtained in the next year a place as privatdozent in Breslau. Freytag very soon abandoned teaching for literature, however, producing several mediocre "situation-comedies" before achieving a solid success with Die Journalisten (1852), which dealt with the rivalry between two newspapers during a local election of little consequence. This comedy was still being played in 1914, but it was the only one of Freytag's works for the stage that did not predecease its author. Freytag left the Prussian capital in 1848 for Leipzig, where he became co-editor of the weekly review, Die Grenzboten. Possibly encouraged by his success with Die Journalisten, he began to write a feature for this Zeitschrift about the life of the ancient Germans which eventually developed into the Bilder aus der deutschen Vergangenheit. 3

Soll und Haben (1855) was Freytag's first novel, a conventional romance set in contemporary life. A second 
attempt at the novel of the present, Die verlorene Handschrift (1864), had a lesser appeal to the public. Freytag had been struck by the popular response to his features on ancient Germanic peoples in Die Grenzboten, and began working his material up into book form. The first of the five volumes of Bilder came out in 1859, the last in 1867, and it was this work that established his literary reputation as the unofficial historian of the German people.

It was in consequence of this reputation that Freytag was invited to accompany the Crown Prince of Prussia during the 1870 campaign in France, an experience which inspired him to begin Die Ahnen, which came to six volumes between 1872 and 1880. This was Freytag's last work, done from the semi-retirement he maintained until his death in 1895.

Die Ahnen traces one German family through fifteen hundred years of history, and Freytag makes the members of this family participate in all the decisive events of that history. Die Ahnen is a fictionalized rendering of Bilder, and may be passed over with the remark that the style and form of the novels bears a resemblance to the Waverley series of Walter Scott, and should be regarded as an example of German romantic fiction even though they were published well after the romantic movement had lost its freshness and early vigor.

The Bilder is informal historical narrative couched in a conversational tone, intended to be accessible to 
the casual reader. As an historian, Freytag is a nonprofessional writing for non-professionals. Sharing Michelet's desire to "resurrect" past generations, Freytag wants to resurrect the common and ordinary and not only the exceptional and extraordinary, which have, in his opinion, been exaggerated in history as it is usually written:

He who wishes to put together the portraits of our earlies forebears only from the features which written history and tales of heroes have left behind will give them a false aspect. The old sources only give us the unusual, while everyday life, which is for us most 4 important, is seldom, as if by accident, preserved.

The Alltägliche, the "everyday life" of the tribal Germans is crucial to Freytag because he saw in it the evidence of a "Germanness" in its earliest manifestations, and which possessed a beauty shared by all later generations of Germans.

As the body of a child has a charm and grace which is his alone, which is absent at every later age and is not at any stage of life replaced by another, so the life and soul of a gifted people in its early youth has a beauty upon which its descendants draw and of which they are the consequence. 5

Freytag's "Germanness" is at bottom the noble savage created by Tacitus in Germania. Though aware of the problems with Germania as a historical source, Freytag summarily dismissed them and urges that Tacitus be taken at his own word because his only motive in Germania was the recording of his personal impressions. Freytag is of 
course implying that Tacitus' impressions were not mistaken because he was a well-educated and refined individual:

The Germania was not composed with the rhetorical intention of presenting a whitewashed contrast to the Romans, but with the sentiment which is inspired in 6 high-minded man by pleasant personal impressions.

Freytag makes here no disguise of the wholly uncritical approach to Tacitus which will determine the "Germanness" he defines in the pages of Bilder, and the "Germanness" emerging from Bilder is essentially an elaboration of that first retailed by Tacitus. All of the traits recorded by Tacitus which might possibly be interpreted as positive are emphasized by Freytag, while other traits, such as the propensities of the early Germans to drunkenness and gaming, are ignored.

Freytag pictured the typical pre-invasion German as a farmer, whose pride in the land he worked was the source of the beginning of a national consciousness. This typical German thought of himself not merely as a worker, but as a proprietor of his land.

It is clear that such [proprietary] ways of thinking, when they are widespread among farming peoples without a monetary economy, indicate the nascence of a national symbolism which will be decisive for the nation. 7

It is obvious that Freytag attributed the nationalistic aspirations of his own century, in a nascent form, to the tribal Germans of the invasion period. This sort of anachronism is precisely what many Germans of the 1860 's 
and 1870's found so appealing; in working toward national unification they were striving to realize a state of affairs which their ancestors of the fifth century had also recognized, if dimly, as desirable.

For Freytag, any "Romanization" of the Germanic peoples who made the move into Gaul was at most minimal. The Roman culture was already waning in Gaul at the time the invasions took place; this culture was too enervated to effect any essential alterations in the essential "Germanness" of the pre-invasion period. To reiterate, Freytag's "Germanness" was a romantic elaboration of the positive traits appearing in Germania. "Germanness" had maintained itself unaltered through fifteen centuries.

Our spiritual life, the way we take up the world and mirror it in our souls, our characteristic inclinations and weaknesses, our idealism, and the origin of our customs as well as the golden treasure of our language are a family inheritance from the Germanic peoples of Tacitus, a heritage which with irresistible power shapes within us all of the 8 spirit, thought, and invention of German life.

The above citation may be fairly regarded as an abstract of Freytag's multi-volume Bilder. It is tempting to dismiss pronouncements such as these as Gruderzeit Schwärmerei, but to do so would be to overlook their value as a source for the study of German nationalism in the last decades of the nineteenth century.

The focus here will be on German nationalism of the $1870^{\prime}$ 's and $1880^{\prime}$ 's, since it was that to which Freytag 
contributed, and since it was only after 1871 that Germans had a nation-state to serve as the object of a "nationalism" as defined in an earlier chapter. The sense of national consciousness first awakened by the War of Liberation was never completely dissipated by the ensuing political reaction of the $1820^{\prime} \mathrm{s}$ and $1830^{\prime} \mathrm{s}$, but it was a source of frustration rather than inspiration. Many of the writers of the "Young Germany" movement may be regarded as nationalists-without-a-nation; Heinrich Heine was one of these. ${ }^{9}$ Nationalism is nowhere a simple matter. In France a Michelet and a Guizot might draw their nationalism from different sources, but they at least had a political state in common. In Germany there was a sense of national identity long before there was a nation-state to serve as its focus 10

Whether inevitably or not, the German nation which made its debut in 1871 was the work of Bismarck, who did no work unless it was in the interest of the kingdom of Prussia. Those men elsewhere in Germany who desired unification along other lines were outmaneuvered by a consummate politician who knew well how to exploit the differences between them. For those, however, who thoroughly identified with a Prussia-dominated Reich, 1871 marked the beginning of a glorious age; and Freytag was among them. ${ }^{11}$ 
When one begins to read Freytag's Bilder or Die Ahnen for the first time, one might suspect that the author was perhaps at war with modernity like Hesse's Harry Haller, and whose vivid re-creations of a distant German past were his means of retreat from a German present of very rapid industrialization which was often also very ugly. A close reading of Soll und Haben, however, demonstrates that Freytag was not merely at peace with the changes that had come to German life, but that he welcomed the challenge these new conditions presented to the traditional values of the common people. Soll und Haben vindicates the place of hard work, thrift, honesty and loyalty in the industrialized marketplace. ${ }^{12}$ That these virtues are also rewarded in academic life is the message of Die verlorene Handschrift (which, not so surprisingly, centers around the discovery of a lost manuscript of Tacitus). 13

Freytag was certainly in love with the past; he collected indecipherable shreds and unidentifiable shards whose sole significance was they were old. He was a genuine antiquarian, but he was at the same time very much a man of the present, excited about current events and anxious to communicate his optimism about the future to his countrymen.

Freytag's plays and novels demonstrate that his literary powers were more representational than purely creative, and this has resulted in the omission of his name 
from among the "great" of German literature. As historian, he is faulted for being too creative. Nevertheless, Freytag accomplished what the "great men" of literature and history had neglected to do: he made German history accessible to the average German. How he could do this without "talking down" to his audience Freytag himself tells us in his Autobiography:

The life of the people, which flows in a dark, current beneath political events, had always greatly attracted me--the circumstances, sorrows and joys of millions of humble men and women. 14

Especially heroic, however, were the men and women of the Völkerwanderung. The passages from Bilder cited earlier were chosen as representative of those occasions when Freytag briefly interrupts the narrative to elaborate the image of the ancient Germans as epic heroes. Here is one more example even more explicit:

It is certain that, regarded as a whole, the condition of the Germanic peoples in the first century of our reckoning were a great deal more similar to that of the Greeks of the Epic Age [which was the real model for Homeric poetry] than to that of the earliest society of Roman farmers on the hills of the Tiber. 15

The tribal Germans not only resemble the Greeks of the Homeric Age, but resemble them much more closely than did the Romans.

What made Freytag's appeal to the historically naive reader so irresistible were the repeated reminders that he, as a German, was a direct descendant of those heroic men 
and women of the time of the Völkerwanderung, that the strengths and weaknesses of his own character were one part of a "family inheritance from the Germans of Tacitus." In this way the reader is directly linked by genealogy to the Germanic peoples of the first century. This connection, moreover, is not intellectual but emotional, established through the metaphors of family and blood. It was precisely this emotional appeal that made the sort of history found in Bilder and Die Ahnen so "real" to the general public.

Freytag undertook a democratization of those virtues associated with the German legendary heroes, making them the birthright of every German and not a monopoly of a few mythic Siegfrieds and a noble elite. He wrote the history of the people for the people.

At this point the question of Freytag's integrity must be considered: to what extent did he deliberately distort history in the interests of making it palatable to a lay public? The answer to this is of course that his distortions are considerable, and that the popularity of his work was largely due to this distortion. ${ }^{16}$ But Freytag perhaps ought not to be judged solely as an historian. He was, after all, not a scholar who devoted the whole of his energies to history, but a novelist who wrote about history (Bilder) and wrote stories set in history (Die Ahnen). Freytag dramatized history, but he believed that the drama 
faithfully represented the core of fact on which it was based. Thus historical sources pertaining to the Völkerwanderung were not for Freytag so much a problem requiring critical analysis as a catalogue of possible models with which his fellow Germans would want to identify.

His experience with Die Grenzboten had taught Freytag that many Germans felt somewhat bewildered; their old definitions of who and what they were no longer seemed to make sense in a Germany where traditional social, economic, and political patterns were so rapidly being rearranged. In furnishing his contemporaries with a version of their history which flattered them and also permitted them to gain some perspective on their present confusion, Freytag no doubt quieted the anxieties of many Germans who, like Friedrich Nietzsche or August Bebel, were less than satisfied with the direction in which their country seemed to be moving. This is not to suggest that any large numbers of the disaffected were likely to have a full grasp of the extent of Neitzsche's or Bebel's frustration, or that those few who genuinely shared Nietzsche's unease could have been at all solaced by Freytag. For many, there was nothing to hinder the choice of Lagarde's or Langbehn's "cultural despair" rather than the confident optimism of Freytag.

Heinrich von Treitschke, who considered himself an expert in such matters, judged Freytag's works to be of great value to the nation-state and said so in an address 
in Freytag's honor to the faculty of the University of

Berlin. It deserves to be quoted at some length:

He is the poet who once dared, in times of degenerate taste, to renew the harmony and the purity of form of our classical poetry; in times of trendiness and factitiousness, to again create characters of flesh and blood from the fullness of German life; and since then he has remained for Germans the model of a thinking artist. He is the historian who, concealing laborious research behind a charming exterior, has traced more thoughtfully than any other the development of the German spirit through the centuries. He is the publicist who, without public recognition, bravely fought under the banner of the black eagle until Prussia's history was fulfilled.

Superlatives are customary in such formal appreciations of a colleague's career, but those used by Treitschke on this occasion were not chosen at random. If they contribute to a rhetoric of praise, they also indicate what it was about Freytag and his work that the Prussian state deemed worthy of praise.

Freytag, says Treitschke, writes with a classical "purity of form" in these times of degenerate taste, when men are prey to a mania for division into factions. Freytag's conventional plots and simple style is officially viewed as the proper alternative to emerging experimental styles in literature and is also prescribed as a palliative for the general anxiety of the German people. ${ }^{18}$ When Treitschke mentions that Freytag fought bravely for Prussia until its history had been "fulfilled," he alludes to the unification of 1871 and the militant tones in which Die 
Grenzboten had advocated that solution to the problem of German unity.

Treitschke invoked a classic among usually-empty clichés when, a few lines later, he declared that Freytag's work "belongs to the nation." But Treitschke was right, and for Freytag the cliché comes close to being literally true in the original meaning of the word "nation" as used by Vico. Bilder and Die Ahnen belonged to "the people," because they were written especially for them, in language and with concepts they understood through their own experience. At the same time they belonged to the kingdom of Prussia, which saw their potential for disseminating the view that the movement toward a united Germany dominated by Prussia ought to be welcomed as a re-establishment of the glorious medieval Reich. Treitschke and the rest of the ruling elite in Berlin were well aware that Freytag was encouraging his readers not to regard the Hohenzollerns as the nominal heads of a modern bureaucratic state but as the reincarnation of the Salians and Hohenstaufen, and they were grateful. Treitschke would have been more precise had he used a more specific word than "nation" in the phrase just discussed. Freytag's work belonged as much to the state as to the people; it belonged, quite literally, to the nation-state of Imperial Germany.

The terms in which Freytag conceived the historical process in its largest sense are contained in the word 
Familienerbe or "family inheritance." In stressing that the common character and disposition of his contemporaries was a Familienerbe from the Germans described by Tacitus, Freytag was, as has been shown, connecting his readers with those tribal Germans by means of a metaphor taken from the experience of intimate relationships. Some of his readers were probably content to stop here, but the logical implications go much further.

Precisely because this intimate connection with the past is in the nature of a Familienerbe, it exists between the present generation and all previous ones. By definition, Familienerbe involves a dynamic of "passing on" or "handing down"; and it was in terms of this dynamic that Freytag envisioned the whole process of history. Each generation is given the Familienerbe by its predecessor and, after a brief custody, "passes on" the inheritance to its successor.

For Freytag, historical progression is to be understood only in terms of the Familienerbe. The process of inheritance is by nature one of preservation, and this means that "progress" consists in resisting all change which threatens to alter the Familienerbe and in encouraging changes which assist in its preservation. The experience of each generation is meaningful to the extent that it uses its energies in defense of the Familienerbe. The relative progress or degeneration of a generation, then, is not ascertained in 
relation to any universal standard but only in relation to its own and unique Familienerbe. The debt here to Herder, Fichte, the Grimms, and the Volk concept is obvious.

An inheritance may be of three kinds: biological, legal, or cultural, and Freytag's Familienerbe involves all three. This makes Freytag's conception of history as family history dangerously narrow. Ultimately, the German Familienerbe is fully accessible only to those who have a genetic share in it, because "blood" is the only one of the three credentials which cannot be forged. The Familienerbe is at bottom an identity principle with definite ideological implications.

What made Freytag's Familienerbe metaphor so popular with his countrymen was not its capacity for bringing them into a closer relationship with the German past, but that it gave them a definite national identity in terms of that relationship. They were the custodians of a specific Familienerbe in which only Germans could rightfully share. "Germanness" had been defined for them by a process of elimination.

\section{CONCLUSION}

Freytag realized that the future of Germany under the aegis of the Bismarckian system was not without dangers. He wrote to his publisher in 1879:

We are still going to suffer a long time from the circumstance that the political strength of the nation has, for one and a half decades, been 
personified in one man. And, along with all of the good fortune and progress of the age, we are going to have to bear the damage that attaches itself to this kind of domination by a single individual. 19

Freytag was not mistaken, as the years after Bismarck's ouster were to prove. Nevertheless, his doubts were far outweighed by his optimism and faith in a wonderful future for the newly united Germany. He did not hesitate to re-create the Völkerwanderung in such a way that it could contribute to the militant pride deemed necessary to ensure Germany's "place in the sun." It has already been mentioned that the concept of Die Ahnen originated in Freytag's impressions as an observer during the campaign against the French in 1870 .

The Völkerwanderung was the event in terms of which Freytag viewed all of subsequent German history. During the Völkerwanderung, the tribal Germans had proven that they possessed the heroism Tacitus saw in them, and in so doing had set the paradigm for all later generations of Germans aspiring to greatness.

In spite of his antiquarianism, Freytag cherished the Völkerwanderung not so much for itself, as a complex of events in German antiquity, but for its potential inspirational value in the interests of a particular German future. From this angle Bilder and Die Ahnen can be seen to represent a modern form of ancestor-worship conveyed by means of exemplar history. 


\section{NOTES: CHAPTER V}

${ }^{1}$ G. P. Gooch, History and Historians, p. 580 .

2 There are no full-length works on Freytag in English. The following details of Freytag's life were culled from an anonymous introduction to Die Journalisten (Boston: D. C. Heath \& Company, 1889).

${ }^{3}$ At this time Freytag also began to collect old Flugblätter (broadsheets) and posters as sources of popular culture. At the time of his death this collection became a state property, and it still exists. I am not aware that it has yet been thoroughly studied or catalogued.

${ }^{4}$ Bilder aus der deutschen Vergangenheit (Leipzig: S. Hirzel, 1889), p. 88. Where no translator is given, the translation is my own.

$$
\begin{aligned}
& 5_{\text {Ibid., p. }} 102 . \\
& 6_{\text {Ibid., p. }} 30 . \\
& { }^{7} \text { Ibid., p. } 78 .
\end{aligned}
$$

${ }^{8}$ Ibid., p. 35. Jakob Grimm would have endorsed this statement warmly.

$9^{9}$ See Alfred Werner's lengthy introduction to The Sword and the Flame (Based on translations of Charles Godfrey Leland (London: A. S. Barnes \& Company, 1960)), containing much biographical material with a focus on Heine's political poetry and prose.

${ }^{10} \mathrm{~A}$. G. Dickens holds that anti-Italian and antipapal traditions, already long-established before Luther, formed the deepest bedrock of German national identity (The German Nation and Martin Luther (New York: Harper \& Row, 1974)).

${ }^{11}$ Nevertheless, there were differences of opinion about the new Reich even among the Prussians. For instance, Wilhelm I's reluctance to assume the title of Kaiser is well known. On this and related identity problems, see Theodor Schieder, Das deutsche Kaiserreich 
von 1871 als Nationstaat (Cologne \& Opladen: Westdeutscher Verlag, 1961), especially the chapter "Symbole und Namen des Nationstaates" ( $p p, 72-88$ ).

${ }^{12}$ In his superlative work on Lagarde, Langbehn, and Moeller van den Bruck, Fritz Stern identified what he called a "Germanic ideology" in their writings (The Politics of Cultural Despair: A Study in the Rise of the Germanic Ideology (Berkeley: University of California Press, 1961). Stern isolated three elements of this "Germanic ideology": an antipathy to modernity; the advocation of a return to a mythical Deutschtum; and the promotion of a militant nationalism. Only the latter two can apply to Freytag. His belief in the viability of traditional values and his alliance with modernity preserved him from the "cultural despair" which afflicted Lagarde, Langbehn, and Moeller van den Bruck.

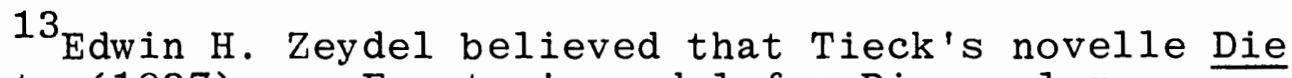
Gelehrte (1827) was Freytag's model for Die verlorene Handschrift (Ludwig Tieck, the German Romanticist, p. 296), and the points of correspondence between the short story and the novel seem too numerous to be coincidental.

${ }^{14}$ Quoted in Gooch, p. 578.

15 Bilder, p. 55.

16 This observation also applies to the English historians Freeman and John Richard Green, whose "Saxonist" idealizations were developed in conversational narratives similar to the style of Bilder and which were likewise intended for consumption by an uninitiated public.

17 Treitschke, Historische und Politische Aufsätze (Leipzig: S. Hirzel, 1897), p. 443.

${ }^{18}$ Freytag avoided the experimentation with 1iterary style of which his mentor Tieck was so fond. He held himself aloof from the Naturalism into which Gerhard Hauptmann was moving at this time, and would probably have agreed with the censors who objected to Die Weber (1892) on the grounds of its implicit "socialism." On the Naturalism of the early Hauptmann see Karl S. Guthke, Gerhard Hauptmann. Weltbild im Werk (Göttingen, 1961).

19 Quoted in Gordon A. Craig, Germany 1866-1945 (New York: Oxford University Press, 1978), p. 60 . 
CHAPTER VI

\section{HISTORICISM, NATIONALISM, AND ROMANTICISM IN MICHELET AND FREYTAG}

Frederich Nietzsche, certainly one of the least sentimental observers of his own times, had this to say about the nineteenth century's fascination with history:

Man today, stripped of myth, stands famished among all his pasts and must dig frantically for roots, be it among the most remote antiquities. What does our great historical hunger signify, our clutching about us of countless other cultures, our consuming desire for knowledge, if not the loss of myth, of a mythic home, the mythic womb? ${ }^{1}$

Nietzsche conceived the role of historian as that of a certain type of myth-maker for whom there was no room in his philosophy. In the Genealogy of Morals Nietzsche wrote that history is usually written in a way that restricted human possibilities. To the "art of remembering" as practiced by most historians Nietzsche opposed an "art of forgetting," which in his philosophy is one of the characteristics of the Übermensch.

With his awareness of the many uses of history, Nietzsche was in an excellent position to pose as a judge of much of the history written during the second half of the nineteenth century. Michelet and Freytag would stand condemned by Nietzsche for pernicious use of the "art of 
remembering," primarily because the "glorious pasts" they offered in their narratives was so inseparable from their nationalism. Nietzsche interpreted nationalism as one of the many diseases stalking his century.

Regardless of what one thinks of Nietzsche, the narratives of Michelet and Freytag did furnish the French and Germans with one sort of "mythic womb." Both writers gave their readers the roots for which they were so frantically digging. Michelet and Freytag not only indicated where these roots were buried, but extracted them and displayed them attractively.

This last is fairly obvious and simple; Michelet and Freytag were answering a general demand for national history which could make a confusing present appear an intelligible outcome of a less complicated past.

But why did these writers choose to present the histories of their respective peoples in the ancient style of "glorious deeds of our ancestors"? It was because they were fulfilling the role of priests in national rites of ancestor-worship. Of course, neither they nor their public regarded their work as inculcating ancestor-worship, but this is essentially the mentality involved. In reminding their countrymen of the glorious deeds of their ancestors, Michelet and Freytag were calling on them for the performance of comparable glorious deeds in the present and in the future. 
Michelet's "free spirit" of the ancient Celts was made to define "Frenchness" and to explain the entire development of France-as-kingdom to France-as-nation-state. Each crucial moment in French history is interpreted by Michelet in terms of the supposed Celtic "free spirit." For instance, Michelet was not the first and will not be the last to identify Joan of Arc with Frenchness, but his identification depends entirely on the "free spirit" which she presumably possessed in abundance. And so it goes throughout the History of France. From its beginnings to its culmination in 1789 , whatever makes French history peculiarly "French" in Michelet's eyes is directly or indirectly attributed to the ancient Celts, who are therefore the ancestors of all "true" Frenchmen.

It was shown in the preceding chapter that Freytag assigned this same function to the tribal Germans in his conception of the German past, and there is no need here to further elaborate the point. What requires stress is that Michelet's Celts and Freytag's Germanen of the Völkerwanderung are virtually identical. They function in the narratives as the sources and reservoirs of Frenchness and Germanness. More than this, they can do no wrong, since even their failings and lack of sophistication are a part of their charm. Whatever distinctions may be made between Michelet's Celts and Freytag's Germanen do no more than point to family variations within the species "noble 
savage." These noble savages are indispensable because they "set the stage" for everything following them. To borrow Nietzsche's terms, they once and for all determine the possibilities of their descendants. Those who choose to criticize the example of the ancestors are not only traitors to family, but traitors to the larger "family" of the nation-state.

The materials for a mythic portrayal of the Celts of Gaul had existed for centuries in France, and it was Michelet's good fortune to have had access to many of them. Freytag needed to look no further than the Germania for the mythic possibilities of the tribal Germans. The "honor" of the Roman senatorial class and the eloquence of Tacitus himself were Freytag's answer to criticisms of this text.

Were Michelet and Freytag historicists? Yes and no. Yes, because they concentrated on what they supposed to be the unique characteristics of "Frenchness" and "Germanness," and no, since they lacked the sense of anachronism which is a necessary a priori of an historicist conception of the past. In other words, they employed an historicist emphasis on differences rather than similarities to construct exemplar histories of the French and German nations.

Despite their commitment to the present and their concern for the future, Michelet and Freytag were actually closer to the medieval chroniclers like Gregory of Tours, 
who embroidered the mythic descent of the Franks from Homeric exiled Trojans, than they were to many of their contemporaries engaged in writing history. Neither subjected his materials to the rigorous analysis practiced by Ranke. Even the broadest definition of historicism must include a sense of "otherness" of the past. This sense was very weak in Michelet and Freytag, since what impressed them in contemplating the past (to twist D. R. Kelley's phrase) was not change, but permanence.

Michelet and Freytag focused on an underlying "sameness" of the past in order to develop their respective definitions of national character. For both writers, their respective nation-states were only the most recent expression of an unchanging ethnic identity. This implied that a genuine reverence for the memory of one's ancestors required that the nation-state, as one part of their legacy, ought also to be revered. The dictates of the nation-state could be thought to contain echoes of the voices of ancestors whom one ought to obey. By this reasoning, assent to whatever is requested by the nation-state becomes no less than a moral duty for all conscientious citizens.

The nation-state became the focus of primitive and romantic conceptions of ethnic group identity, and these concepts were utilized by the caretakers of the nationstate to preserve and aggrandize its position in the interests of culture, civilization, and morality. This was 
the internal development of nineteenth century nationalism, which is inseparable from the developments in international politics.

The sense of national identity among the French was given a universalist cast during the French Revolution, but the wars of the Revolution tended to mute the abstract ideals which were central to the first surge of French nationalism and to infuse it with an enduring militancy. For most Frenchmen, nationalism became an identity principal with which to flatter themselves. A sense of national identity among the Germans was forcibly and rapidly transformed into militant nationalism without, except in the minds of such cosmopolites as Görres and Fichte, passing through a phase of abstract and universal values. This cannot be attributed to any mysterious German antipathy to an equally mysterious "western heritage" with which the ideals of 1789 are so often associated. It was the direct consequence of French occupation of the German territories. Germans had not the luxury of being nationalistic in the name of universals, because their variety of militant nationalism took shape in the process of resisting a very real foreign domination. After 1815, universalist liberal ideals received from the German governments in general even less toleration than they had before the French Revolution. The political unity achieved in 1871 finally gave Germans a nation-state, but this again 
required that their nationalism be militaristic, since unification had been to a large extent contingent on the military successes against the French. When, toward the close of the century, universalism reappeared in German nationalism, it was manifested not so much in the cosmopolitan sentiments Herder and Fichte would have recognized as in a desire to take the blessings of German Kultur to the four corners of the earth. To be sure, there were idealists in the Pan-German League, but theirs was a militant idealism focused on the global competition for colonies and "spheres of influence."

In terms of French and German nationalism, Michelet and Freytag added their voices to a general escalation of mutual antagonism. Although neither of them was a xenophobe à la Jahn, both of them chose not to question their deep reverence for the mutually exclusive claims of their respective nation-states. A mutual French-German antagonism certainly pre-dated the French and German nations, but it first assumed unprecedented extremes of viciousness in the first half of the nineteenth century. In the second half, this antagonism was made even grimmer by the FrancoPrussian War.

This short war left plenty of long-lasting recollections on both sides to fuel the hatred which finally found such a sad consummation between 1914 and 1918. Men from one side of the Rhine set off to avenge Sedan, and from the 
other side to teach the French their place a second time. And among their confused notions of national honor were also visions, on one side, of those ancient Celts who alone knew the true meaning of freedom, and, on the other side, images of tribal farmer-warriors whose route they were retracing. Such visions would have existed without Michelet and Freytag, but not so vividly for so many. Hayden White, in his Metahistory, uses the terminology of literary criticism to demonstrate that modern histories may be "emplotted" in any one of four ways: as Romance, Tragedy, Comedy or Satire. ${ }^{2}$ These are the "archetypal" structures found in any narrative more elaborate than mere chronicle, which usually displays the structure of Epic. White associates a prominent nineteenth century historian with each of these emplotments. Tocqueville is linked with history-as-Tragedy, Ranke with history-as-Comedy, and Burckhardt with history-as-Satire. Michelet is made the representative writer of history-asRomance. ${ }^{3}$ White defines Romance in these terms:

The Romance is fundamentally a drama of selfidentification symbolized by the hero's transcendence of the world of experience, his victory over it, and his final liberation from it--the sort of drama associated with the Grail legend or the story of the resurrection of Christ in Christian mythology. It is a triumph of good over evil, of virtue over vice, of light over darkness, and of the ultimate transcendence of man over the 4 world in which he was imprisoned by the Fall. 
The hero in Michelet's conception of French history has been shown to be "the people" of France; the Grail of French history to be individual freedom for the people; and the "ultimate transcendence" to have been achieved in the year 1789. In this sense, the History of the French Revolution represents the denouement of the multi-act drama recorded in the History of France.

In Freytag's conception of German history it is also the "millions of humble men and women" who assume the persona of a hero struggling against a harsh world. The quest of the German people, however, is for a unity they had already gained and lost again in the Middle Ages, and which was once more established by the political unification of 1871 .

\section{CONCLUSION}

The work of Jules Michelet and Gustav Freytag has been treated here as primary source material on the close relationship between literary romanticism and political nationalism in the late nineteenth century. An attempt has been made to demonstrate that their divergent interpretations of the early medieval Germanic invasions of Gaul were expressed in the form of romantic narratives which faithfully mirror their respective nationalistic commitments. From a political standpoint, Michelet and Freytag made a potent contribution to the increasingly militant 
nationalism of their respective countries, since their interpretations of French and German national character as having been once and for all determined in the early Middle Ages tended to grace the contemporary antagonism between France and Germany with the sanction of historical inevitability. The mutual hatred and mistrust between the French and the Germans was not regarded merely as a fact of contemporary politics, but also as an aspect of the working out of the historical "destinies" of the two peoples. That Michelet and Freytag indulged enthusiastically in this sort of positivistic metahistory is perhaps the most serious criticism which can be made of them.

They may also be criticized in the more technical area of their historical scholarship and methodology, since their work abounds in omissions, exaggerations, and other distortions of their source materials in the service of their respective ethnic and national loyalties. As historians, Michelet and Freytag cannot be held up as exemplars of detachment or objectivity.

But while these criticisms are fully substantiated by a study of each man's work in itself, certain positive aspects emerge when Michelet and Freytag's views are considered in a context including several other contemporary writers. In order to achieve a fuller understanding, the criticisms just mentioned must be balanced with a less judgmental consideration of their work in relation to that 
of some of the other individuals who have been briefly treated in this study.

Returning to the question of national prejudice, it is clear that neither Michelet or Freytag took a position anywhere near the extreme which can be said to be exemplified by the thought and activity of Ludwig Jahn. On the other hand, neither was their outlook cosmopolitan in the sense of Herder or the French philosophès. Given the fact that they undertook to write specifically national histories in an atmosphere charged with a mutual FrenchGerman xenophobia cultivated by men like Jahn, it is remarkable that Michelet and Freytag managed to maintain a relative moderation in their views. In a climate of unreasoning national pride on both sides of the Rhine, neither was unwilling to recognize flaws in the collective character of his countrymen. Though both were quick to add that these flaws were integral to an overall excellence, their acknowledgement of negative as well as positive components of "Frenchness" and "Germanness" is a measure of their relative objectivity. Their English counterparts Freeman and John Richard Green were unable to achieve as much in regard to their Anglo-Saxon "Englishness," as were a host of lesser writers of popularized history for a mass public, and who made their own national group the possessor of all virtues. 
Since nationalism is a political phenomenon which is also a source of collective and individual identity, race thinking has naturally played a greater or lesser role in definitions of national character. Race, whether considered as an hypothesis or as a biological fact, is for obvious reasons a criterion useful for a division of human beings into discrete groups, each of which are thought to possess a unique identity. In the chapter on Michelet some care was taken to clarify his conception of race. This was done not only because Michelet's conception of race is central to his interpretation of history, but because Freytag understood race in virtually the same terms and likewise made it one of the foundations of his interpretation of history.

Michelet and Freytag used "race" where we would today use the expression "ethnic group." They felt that there was a "French race," a "German race,"; in short, a "race" corresponding to every ethnic grouping in Europe. The emphasis is of course on differences between Europeans rather than on a common European heritage, something which seems unfortunate to many of us today. But here, as in the case of their national prejudices, Michelet and Freytag were within the contemporary mainstream. The assumption that the "white" races were the crown of human evolution was accepted by them as a matter of course, in the same way that it is accepted by many "whites" today. But neither 
was preoccupied with race thinking, or followed it to the logical extremes reached by Gobineau and his disciples. Though Michelet and Freytag are "racists" by present liberal standards, their views on race can be considered moderate in the sense that they avoided extremes in their race thinking as they avoided them in their nationalism.

Michelet and Freytag did not follow Gobineau in calling for a return to an original "purity of the races" since, for different reasons, neither believed this to be either possible or desirable. Despite the affection lavished by Michelet on his "ancient Celts" of Gaul, it was still the French Revolution which had determined the direction in which France and the French must develop. It was to the year 1789, and not to the Celts of the fifth century and earlier, that the French must look in building the future.

Freytag's introduction to Bilder aus der deutschen Vergangenheit takes the form of an admonition. He cautions he readers against the natural temptation to think of the past as "the good old days," pointing out that until relatively recently life had been short and comforts few. Though Freytag tended to disregard his own advice, that he gave it at all indicates that he was aware of the pitfalls of studying the past for its own sake; he felt that it could be more usefully studied for an understanding of the 
present and as a source of inspiration for the shaping of an even greater future for Germany.

It is obvious, then, that Michelet and Freytag were unable to advocate any sort of "return" to the Middle Ages along the lines envisioned by Novalis or Chateaubriand, who were so much out of sympathy with the politics and culture of their day that they could make their discomfort tolerable only by a fanciful escape into an idyllic medieval Christendom. Michelet and Freytag were men solidly rooted in the present, and were reasonably comfortable there. Although Michelet gave way to despair after the French defeat in 1871, he had until then been inclined to interpret problems as a challenge to their future solution. Freytag was more fortunate, being able to sustain this sort of optimism all of his life. Granted that a present and future orientation in regard to their respective nations marred Michelet's and Freytag's work as historians, it does not follow that such an orientation, used more carefully, has no place at all in historical writing. Like the Grimm brothers, Michelet and Freytag knew a good story when they heard it, and were prone to exercise their talents as storytellers at the expense of their obligations as historians.

This last point deserves elaboration, since even their severest critics will not deny that Michelet and Freytag were master storytellers. It is no wonder that 
their narratives had the effect of determining the shape and significance of the national past for historically naive readers when one remembers that the credibility of any story is a function of how well it is told. There is every reason to conclude that it is as masters of the art of storytelling rather than as historians that Michelet and Freytag can be most fully understood. Such an approach allows one to take into account their shortcomings while also recognizing their achievement, which was the presentation of French and German national history in the form of a story involving every French and German reader.

These considerations suggest that especially instructive parallels exist between Michelet and Freytag and the Grimms, who made stories and storytelling a legitimate subject of serious study. Michelet's admiration of their work was noted earlier, while Freytag's interests were so similar to those of the Grimms that a demonstration of their influence on him is not strictly necessary. Michelet and Freytag approached their material as collectors, selecting the anecdotes and events potentially most capable of eliciting a certain definition of "Frenchness" and Germanness," and then making these chosen elements the basis of romantic narrative. The Grimms collected thousands of folktales and then composed "archetypical" versions of a more manageable number of tales of specific types. These "archetypical" tales display a romantic coloration 
not present in the originals from which they were drawn. This is to say that not only did Michelet, Freytag, and the Grimms handle their sources in a similar fashion, but they expressed the results of their work in an identical literary style.

In the process of classifying German folktales, the Grimms identified two primary types of tale. Märchen or fairy-tales are not specific to any time or place, and are often based on universal human fears and wishes. Sagen or legends, however, are always located in a specific place and time, and are often based on verifiable events so that they have an historical nature. Further, Sagen tend to express the peculiarities of the group which preserves them. Using this distinction between Märchen and Sagen in a final return to Michelet and Freytag provides emphasis to the conclusion that the most enduring value of their work will be as Sagen of the late nineteenth century. It is certainly true that what they wrote and the way they wrote it can tell a student as much about their own time as it can about the earlier history of their nations. 
NOTES: CHAPTER VI

$1_{\text {The Birth of Tragedy out of the Spirit of Music, }}$ translated by Francis Golffing (New York: Doubleday \& Co. , $1956)$, p. 137 .

2 Metahistory: The Historical Imagination in Nineteenth Century Europe (Baltimore: Johns Hopkins University Press, 1973), p. 7 .

${ }^{3}$ Ibid., p. 8, and Chapter 3, pp. 135-162.

${ }^{4}$ Ibid., pp. 8-9. 


\section{A SELECTED BIBLIOGRAPHY}

\section{WORKS BY FREYTAG AND MICHELET}

Freytag, Gustav. Die Ahnen. Leipzig: S. Hirzel, 1889.

-.---.--. Bilder aus der deutschen Vergangenheit. Leipzig: S. Hirzel, 1889.

-........ Die Journalisten. Boston: D. C. Heath \& Company, 1889 .

-..--.-.- Soll und Haben. Leipzig: S. Hirzel, 1916.

Michelet, Jules. France before Europe. No translator given. Roberts \& Brothers, 1871.

Smith. New York: Appleton \& Company, 1882.

-.---. The History of the French Revolution. Trans. G. Cocks. Ed. Gordon Wright. Chicago \& London: University of Chicago Press, 1967.

- The People. Trans. John P. McKay. Urbana: University of Illinois Press, 1973. 


\section{RELATED PRIMARY SOURCES}

Caesar, Julius. Commentaries on the Gallic War. Trans. Edward Brooks. Philadelphia: David McKay, 1896.

Chateaubriand, Francois René. Atala and René. Trans. Irving Putter. Berkeley \& Los Angeles: University of California Press, 1967.

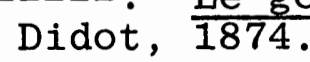

-.-.-.. Les martyrs du Diocletien. No translator given. J. M. Dent \& Sons, 1912.

- Memoirs. Trans. Robert Baldick. New York: A. Knopf, 1961.

Dalton, O. M., ed. History of the Franks. 2 vols. Oxford: Clarendon Press, 1926. Gregory of Tours' text in Vol. 2, with extensive explanatory footnotes. Vol. 1 consists of Dalton's introduction to the text and to Merovingian period in general, which, though dated, is useful to the beginning student.

Grimm, Jacob. Über der Ursprung der Sprache. Wiesbaden: Insel-Ver lag, 1958.

Grimm, Jacob and Wilhelm. Deutsche Mythologie. Darmstadt: Wissenschaftliche Buchgesellschaft, 1965.

- Deutsche Sagen. Munich: Winkler, 1956.

2 vols. The German Legends of the Brothers Grimm. Philadelphia: Institute for the Study of Human Issues, 1981.

Guizot, Francois. History of Civilization in Europe. No translator given. New York: A. L. Burt, 1880 .

-----. History of Civilization in France. Trans. G. Cocks. Chicago: University of Chicago Press, 1972.

Herder, Johann Gottlieb. Ideen zur Philosophie der Geschichte der Menschheit. Leipzig: Biographisches Institut, 1887 . 
Jäger, Oskar. Weltgeschichte. 2 vols. Leipzig: Velhagen \& Klassing, 1887 .

Knox, Robert. The Races of Men. Philadelphia: Lea \& Blanchard, 1850 .

Koch, Willi A., ed. Briefe deutscher Romantiker. Leipzig: Dieterich'chen Verlagsbuchhandlung, 1938.

Meinecke, Friedrich. Die Entstehung des Historismus.

Trans. as Historicism by J. E. Anderson. New York:

Herder \& Herder, 1972.

------. Weltbürgertum und Nationstaat: Studien zur Genesis der deutschen Nationstaates. Ed. and with an introduction by Hans Herzfeld. Vol. 5 of collected works. Munich: Oldenbourg, 1962.

Nietzsche, Friedrich. The Birth of Tragedy Out of the Spirit of Music. Trans. Francis Golffing. New York: Doubleday, 1956.

Novalis (Friedrich von Hardenburg). Werke. Stuttgart:

W. Hadecke, no date (1920's).

Ridpath, J. C. History of the World. Cincinnati: Jones Brothers, 1894 .

Riehl, Hans. Die Völkerwanderung. Bergisch-Gladbach: Gustave Lubbe Verlag, 1976.

Sismondi, J. L. C. History of the Fall of the Roman Empire. London, 1834.

de Staël, Germaine. Madame de Stael on Politics, Literature, and National Character. Trans. and ed. Morroe Bergen. Garden City, N.Y.: Doubleday \& Company, 1964.

- Ten Years of Exile. Trans. Doris Biek. New York: Saturday Review Press, 1972.

Tacitus, Cornelius. Dialogus, Agricola, Germanica. London: W. Heinemann, 1914.

Thierry, Augustin. History of the Conquest of England by the Normans. No translator given. New York: Everyman's, 1906.

- - N- Narratives of the Merovingian Era. No translator given. London: Wittaker \& Company, 1845. 
von Treitschke, Heinrich. Historische und Politische Aufsätze. Leipzig: S. Hirzel, 1897.

Vico, Giambattista. The Autobiography of Giambattista Vico. Trans. and with an introduction by Max Harold $\overline{\text { Fisch }}$ and Goddard Bergin. Ithaca: Cornell University Press, 1944.

The New Science. Trans. and with an introduction by Max Harold Fisch and Goddard Bergin. Ithaca: Cornell University Press, 1948. 


\section{SECONDARY MATERIALS}

Atherton, John. "Michelet's Three Conceptions of Historiical Being." Studies in Romanticism, 4, No. 4 (1965), 220-239. Relates Michelet's interpretations to the "three ages of man" described by Vico.

Baker, John R. Race. New York: Oxford University Press, 1974. A textbook exposition of current racethinking.

Banton, Michael. The Race Concept. New York: Praeger, 1975. A capable survey of this concept from the etymology of the word "race" to present times.

Barzun, Jacques. Classic, Romantic, and Modern. Garden City, N. Y.: Doubleday \& Company, 1961. Valuable for a broad definition of romanticism which stresses its pre-nineteenth century manifestations.

-- - - - . The French Race: Theories of Its Origins and Their political and Social Implications. New York: Columbia University Press, 1932. covers the period from the Middle Ages to the French Revolution.

-.-.-.. Race: A Study in Superstition. New York: Harper \& Row, 1937. An examination of nineteenth century race theories in a general European context.

Benz, Richard. Die deutschen Romantik. Geschichte einer geistigen Bewegung. Leipzig: Phillip Reklam, 1937. This work reflects the propensity of Benz's generation to "patriotize" the German romantics.

Berlin, Isaiah. Vico and Herder. London: Hogarth, 1976. The thought of the two men contrasted and compared.

Biddiss, Michael D. The Father of Racist Ideology: The Social and Political Thought of Gobineau. London: Weidenfeld \& Nicolson, 1970. A definitive work on Gobineau and his influence.

Borchardt, Frank L. German Antiquity in Renaissance Myth. Baltimore: Johns Hopkins Press, 1977. The legendary descent of the Franks and other origin legends examined. 
Brandes, Georg. Main Currents in Nineteenth Century Literature. New York: Boni \& Liverwright, 1922. 9 vols. A dated but valuable introduction to German romanticism (Vol, 2) and French romanticism (Vol. 5).

Brogan, D. W. French Personalities and Problems. New York: A. Knopf, 1947. Contains a critical review of Hans Kohn's The Idea of Nationalism and E. H. Carr's Nationalism and After.

Burke, Peter. The Renaissance Sense of the Past. London: Edward Arnold, 1969. Background on the tradition of exemplar history; classical antiquity as providing models for "the good Prince" and "the good subject."

Caponigri, A. Robert. Time and Idea: The Theory of History in Vico. Chicago: Regenery, 1953. The implicit relativism in the vichian view is stressed.

Carr, Edward H. Nationalism and After. New York: Macmillan, 1943. An analysis made poignant by the author's belief that nationalism would no longer be a significant factor in world politics after the Second World War.

Chadwick, N. Munro. The Nationalities of Europe and the Growth of Nationalistic Feeling. New York: Cooper Square, 1945. Argues the inevitability of nationalism from "primary feelings," i.e., instinct.

Christoff, Peter K. The Third Heart. The Hague: Mouton, 1970. An examination of the romantic underpinnings of the "slavophile" movement.

Clark, Kenneth. The Romantic Rebellion. London: Harper \& Row, 1973. Attention is given to the interrelationships of classical and romantic aesthetics.

Clement, N. H. Romanticism in France. New York: Modern Language Association of America, 1939. Heavy stress on the political involvement of Chateaubriand, Hugo, and others.

Craig, Gordon. Germany 1866-1945. New York: Oxford University Press, 1978. Contains good sections on German 1iterature. 
Croce, Benedetto. The Philosophy of Giambattista Vico. Trans. R. G. Collingwood. New York: Russell \& Russell, 1964. The stress is on those elements in Vico which accord with the author's view of history as art.

Dawson, Christopher H. The Gods of Revolution. New York: New York University Press, 1972. Jacobins and Jacobinism as purveyors of a "religion of reason."

Deutsch, Karl W. Nationalism and Its Alternatives. New York: A. Knopf, 1969. An optimistic evaluation of the possibilities of avoiding a nuclear conflagration.

Dickens, A. G. The German Nation and Martin Luther. New York: Harper Y Row, 1974. A survey of the traditions of a German identity in the pre-Reformation era.

Dmytryshyn, Basil, ed. Imperial Russia: A Source Book, 1700-1917. New York: Holt, Rinehart and Winston, 1967. Contains Herzen's critical letter to Michelet.

Engelbrecht, H. C. Johann Gottlieb Fichte: A Study of His Political Writings with Special Reference to His Nationalism. New York: Columbia University Press, 1933. A contextual study which brings out Fichte's enduring cosmopolitan outlook.

Finch, N. B. The Origins of French Romanticism. New York: E. P. Dutton, 1920. Little analysis but much biographical detail. Elements of romanticism traced in French writers from Diderot to the Restoration of 1815 .

Fishman, Joshua A. Language and Nationalism. Rowley, Mass.: Newbury House, 1972. A sociological approach. Offers a review of nineteenth century "purification" of language, but focus is on contemporary efforts of the same kind.

Frenzel, Herbert and Elizabeth. Daten deutscher Dichtung. Koln: Kiepenheur und Witsch, 1953. A useful source for chronologies of German literary figures.

Furst, Lillian. Romanticism. Vol. 2 of the "Critical Idiom" series ed. by John D. Jump. London: Methunen, 1969. An exposition of the strict, literary definition of romanticism. Criticisms of Barzun's definition. 
-.-.-.-. Romanticism in Perspective. London: Macmillan, 1969. Comparative study of romanticism in England, France, and Germany.

Gooch, G. P. History and Historians in the Nineteenth Century. New York: Longmans, Green \& Company, 1920. Valuable for its detail.

Gossmann, Lionel. Medievalism and the Ideologies of the Enlightenment. Baltimore: Johns Hopkins Press, 1968. An exploration of the interests of several "enlightened" French scholars in the Middle Ages.

Guthke, Karl S. Gerhard Hauptmann. Weltbild im Werk. Gottingen, 1961. Hauptmann's early allegiance to Naturalism and his later development demonstrated by citations of his work.

Gutwirth, Madelyn. Madame de Staël, Novelist. Urbana: University of Chicago Press, 1978. A focus on de Staël as a pioneering figure in the movement of women into the world of literature.

Haller, John S. Outcasts from Evolution: Scientific Attitudes of Racial Inferiority, 1859-1900. Urbana: University of Illinois Press, 1971. An examination of the respectability conferred by science on racism.

Hampson, Norman. The First European Revolution 1776-1815. London: Thames \& Hudson, 1969. The American and French revolution viewed in a cultural context.

Hayes, Carlton, J. H. Essays on Nationalism. New York: Macmillan, 1928. A classic study of the origins of modern political nationalism and its definition.

Haym, Rudolf. Die romantische Schule. Berlin: Weidmann'sche Verlag, 1870. A critical study of German romantics, valuable for detail and mastery of previous criticism.

Huch, Richarda. Die Romantik: Blutezeit, Ausbreitung, und Verfall. Tubingen: Rainer Wunderlich, 1951. A partisan treatment saved by the merit of its insight.

Huppert, George. The Idea of Perfect History. Urbana: University of Illinois Press, 1970. A thorough study of Renaissance historiography. 
Iggers, Georg G. The German Conception of History. Middletown, Conn.: Wesleyan University Press, 1968. A survey from the idealism of Hegel to the relativism of Meinecke.

Jones, Howard M. Revolution and Romanticism. Cambridge, Mass.: Harvard University Press, 1974. Excellent general survey with attention to the interrelation of politics and culture.

Kamenka, Eugene, ed. Nationalism: The Nature and Evolution of an Idea. New York: St. Martin's Press, 1976. Nationalism in perspective; essays by several scholars treat both nineteenth century and contemporary nationalism.

Kedourie, Elie. Nationalism. London: Hutchinson University Library, 1960. A good brief treatment of the origins of nationalism in selected thinkers of the eighteenth and nineteenth centuries.

Kelley, D. R. Foundations of Modern Historical Scholarship. New York: Columbia University Press, 1970. A study of several elements of the modern conception of history anticipated by French humanists.

Kluckhohn, Paul, ed. Deutsche Vergangenheit und deutscher Staat. Darmstadt: Wissenschaftliche Buchgesel1schaft, 1966. Vol. 5 of a multivolume series on German literature. An anthology of writings by German romantics concerning their feelings of national identity.

Kohn, Hans. The Age of Nationalism. New York: Harper \& Row, 1962. A critical treatment of nationalism in the major European nation-states.

-----. Prelude to Nation-States. Princeton: Van Nostrand, 1967. Focuses on the French-German antagonism as a determinant of modern nationalism.

Kollectiv für Volksgeschichte. Romantik. Berlin: Volkseigenen Verlag, 1967. German romanticism examined in Lexicon format, with a party-line antiromantic bias.

Lang, David Marshall. The First Russian Radical. London: George Allen \& Unwin, 1959. A comprehensive biography of Radishchev. 
Lavrin, Janko. Russia, Slavdom, and the Western World. London: Bles, 1969. The problem of Russian identity in general outline.

Limberg, Eugen. Geschichte des Nationalismus in Europa. Stuttgart: Schwab, 1951. The common elements of the various nationalisms are stressed.

Lukacs, Georg. The Historical Novel. Trans. Hannah and Stanley Mitchell. London: Merlin Press, 1962. A survey of this literary form from the predecessors of Walter scott to the present.

Mann, Golo. The History of Germany Since 1789. New York: Praeger, 1968. An interpretative general survey.

Masaryk, Tomas G. Zur russischen Geschichts-und-Religionsphilosophie. Dusseldorf-Koln: Eugen Diederich, 1965. An exploration of the philosophical and religious bases of the "Slavophile" definition of Russian identity.

Michaelis-Jena, Ruth. The Brothers Grimm. London: Routledge \& Kegan Paul, 1970. One of the few English biographies of the brothers; a well-rounded portrayal.

Minogue, K. R. Nationalism. London: Jarrold \& Sons, 1967. The contributions of Herder and Fichte to the later ideology of political nationalism are stressed.

Mosse, George L. Masses and Man: Nationalist and Fascist Perceptions of Reality. New York: Howard Fertig, 1980. A continuation of the line of study laid down in the author's first work. German and French varieties of fascism contrasted.

--------. The Nationalization of the Masses. New York: Howard Fertig, 1975. Excellent analysis of political symbolism and mass movements in Germany from 1800 to 1945 .

Nadel, G. H. "The Philosophy of History before Historicism." Studies in the Philosophy of History:

Selected Essays from History and Theory. New York: Harper \& Row, 1965. Background and definition of exemplar history.

Neff, Emery. The Poetry of History. New York: Columbia University Press, 1947. Chapter 5 is a discussion of Michelet's avowed goal of "resurrection" of the past. 
Neubauer, John. Novalis. Boston: Twayne, 1980. One of the few English biographers of von Hardenburg. Essential detail on the many sides of this personality.

Painter, George D. Chateaubriand. 1st vol.; 2nd vol. still in preparation. New York: A Knopf, 1978. A well documented biography marred by a romanticization of the subject; Chateaubriand's life to the year 1793.

Peckham, Morse. Romanticism: The Culture of the Nineteenth Century. New York: George Braziller, 1965. A study flawed by over-schematization and an implicit assumption that romanticism was the culture of the nineteenth century. These shortcomings mitigated by the apt use of illustrations of art and architecture.

Peuckert, Will Erich. Die Bruder Grimm: Ihr Werk in Grundriss. Leipzig: Alfred Kroner Verlag, no date (1930's). A biography of the brothers built on their correspondence.

Popper, K. R. The Poverty of Historicism. Boston: Beacon Press, 1957. Historicism is repudiated for its relativism.

Porterfield, A. W. An Outline of German Romanticism:

1766-1866. Boston: Ginn \& Company, 1914. A valuable work of bibliography.

Prang, Helmut, ed. Begriffbestimmung der Romantik. Darmstadt: Wissenschaftliche Buchgesellschaft, 1968. A collection of twenty-two scholarly definitions of romanticism, both general and specific.

Raeff, Marc, ed. Russian Intellectual History: An Anthology. New York: Harcourt, Brace, \& World, 1966. Contains Chaadaev's "First Letter" and Kireevskii's "European Culture."

Rearick, Charles. "Michelet as Folklorist-Historian:

Symbol, Legend, and History." French Historical Studies, 11, No. 1 (1977), 72-92. An examination of the influence of the German romantics on Michelet.

Reisiger, Hans. Johann Gottlieb Herder: sein Leben in Selbstzeugnissen, Briefen und Berichten. Darmstadt : Wissenschaftliche Buchgesellschaft, 1970. A biography of Herder built upon his correspondence and acquaintance. 
Robson-Scott, W. D. The Literary Background of the Gothic Revival in Germany. Oxford: Clarendon Press, 1965. An examination of the direct connection between literary romanticism and the neo-Gothic movement in architecture.

Schanze, Helmut. Romantik und Aufklärung. Nuremberg: Hans Kar1, $1 \overline{966 . ~ R o m a n t i c i s m ~ v i e w e d ~ a s ~ n e g a t i o n ~ o f ~}$ classicism.

Schieder, Theodor. Das deutsche Kaiserreich von 1871 als Nationstaat. Cologne \& Opladen: Westdeutscher Verlag, 1961. The problems of German unification examined with attention to the lack of consensus on the content of a national identity.

Seznec, Jean. "Michelet in Germany." History and Theory, 16, No. 1 (1977), 1-10. The possible influence of Riemenschneider wood-sculpture on Michelet is argued.

Shafer, Floyd C. Nationalism: Myth and Reality. New York: Harcourt, Brace and Company, 1955. The first chapter particularly useful as an introduction to the problems of definition.

Stern, Fritz. The Politics of Cultural Despair: A Study in the Rise of the Germanic Ideology. Berkeley:

University of California Press, 1961. A superb study of political and cultural discontent in late nineteenth and early twentieth century Germany.

-- The Varieties of History: From Voltaire to the Present. New York: Meridian Books, 1956. Contains statements by Michelet and Meinecke.

Tagliocozzo, Giorgio, ed. Giambattista Vico: An International Symposium. Baltimore: Johns Hopkins Press, 1969. Essays by a score of scholars.

Talmon, J. I. Political Messianism. New York: Praeger, 1960. Romanticism connected to mass political movements in Europe and to the rise of totalitarian ideologies.

Taylor, R. The Romantic Tradition in Germany. London: Methuen, 1970. Excerpts and commentaries; Herder, Wackenroder, Novalis, the Schlegels, Schopenhauer, and Wagner. 
Thaden, Edward C. "The Beginnings of Romantic Nationalism in Russia." American Slavic and East European

Review, 13 (1954), 500-521. Background essential for an understanding of Chaadaev and Kireevskii. Demonstrates the links of Russian intellectuals with Western Europe.

--.----. Conservative Nationalism in Russia. Seattle: University of Washington Press, 1964. Traces the institutionalization of a nationalism originating in romanticism.

Troeltsch, Ernst. Der Historismus und seine Probleme. Tübingen: Mohr, 1922. Historicism defended against its critics.

Viereck, Peter. Metapolitics: The Roots of the Nazi Mind. New York: Everyman's, 1941. Romanticism impugned as the parent of German fascism.

Wallace-Hadrill, J. M. The Long-Haired Kings. New York: Barnes \& Noble, 1962. A collection of essays on the Merovingian period representative of the current consensus.

Werner, Alfred, ed. The Sword and the Flame: Selections from Heine's Prose. Based on the translations by Charles G. Lealand. London: A. S. Barnes \& Company, 1960. A valuable study; Heine as spokesman for the political aims of the "Young Germany" movement.

White, Hayden V. Metahistory: The Historical Imagination of the Nineteenth Century. Baltimore: Johns Hopkins Press, 1973. Penetrating analysis of Michelet and others in terms of trope-theory and the types of drama.

White, Lynn, ed. The Transformation of the Roman World: Gibbon's Problem after Two Centuries. Los Angeles: University of California Press, 1966. A collection of essays by various scholars.

Wright, Gordon. France in Modern Times. New York and London: Norton, 1981. Good survey of the period since 1789.

Zeldin, Theodore. France 1848-1945. Vol. 2. Oxford: Clarendon Press, 1977. The first chapter discusses the problems of French national identity. 
Zeydel, Edwin H. Ludwig Tieck, German Romanticist. Princeton: princeton University Press, 1935. A literary biography.

Zöllner, Erich. Geschichte der Franken. Munich: C. H. Beck, 1970. A study of the Franks with no discernible nationalistic bias, representative of current consensus in German scholarship. 